\title{
Introduction: Alchemies of the Collective Soul: Scipio Sighele's Crimes and Punishments
}

\author{
NICOLETTA PIREDDU
}

When Mr Barnstaple, the protagonist of H.G. Wells's 1923 novel Men Like God, arrives in the parallel universe of Utopia, he finds himself in a "fortunate world" where "there is no Crowd" (Men 285). If for the stunned Earthling such felicitous discovery constitutes the most extraordinary feature of this civilization many thousand years ahead of his, it also triggers a comparison with his own society, which "alas still is, the world of the Crowd, the world of that detestable crawling mass of un-featured, infected human beings" (285). The contempt for these amorphous collectivities that in Utopia only survive through film and photographs preserved in history museums is summarized by Barnstaple's agitated explanation to Crystal, a young Utopian:

You have never seen a Crowd, Crystal; and in all your happy life you never will. You have never seen a Crowd going to a football match or a race meeting or a bull-fight or a public execution or the like crowd joy; you have never watched a Crowd wedge and stick in a narrow place or hoot or howl in a crisis. You have never watched it stream sluggishly along the streets to gape at a King, or yell for a war, or yell quite equally for a peace. And you have never seen the Crowd, struck by some Panic breeze, change from Crowd proper to Mob and begin to smash and hunt. (285-86)

The mobs that Crystal sees only in the reproductions of thirty centuries before, "streaming over downs after a great race meeting" (286) or "rioting in some public square and being dispersed by the police" 
(286) are, indeed, the protagonists of late nineteenth-century Western societies, where sociologists, psychologists, anthropologists, and philosophers begin to reinterpret the mass from a mere aggregation of singular individuals to an autonomous entity worthy of scientific inquiry. The scholars most commonly associated with the pioneering studies of crowds in that period are the French Gustave Le Bon (1841-1931) and Gabriel Tarde (1843-1904). It has been documented, for instance, that Le Bon's Psychologie des foules (1895) [ The Crowd: A Study of the Popular Mind (1896)] played a crucial role in the development of Mussolini's political ideas, inspired Hitler's Mein Kampf, and was among Lenin's Parisian readings (Ginneken 185-86). Yet also representatives of democracy like Theodore Roosevelt avowed their admiration for the French social psychologist. No matter how faithful to the complexities of Le Bon's vision, supporters of totalitarian and representative regimes alike for several decades after the publication of Psychologie des foules have seen in Le Bon the pivotal contributor to the problem of the relationship between the internal discipline of the individual self and the external discipline that becomes necessary to cope with collective social manifestations under the assumption that self-organization of masses is unrealistic. Even now, the so-called age of crowds ${ }^{1}$ still evokes primarily the late nineteenth-century French context, with the fearful popular uprising leading to the Paris Commune and the numerous disturbing images of masses in novels by Balzac, Sue, Maupassant, Zola, Huysmans, and Adam, among others. ${ }^{2}$

What is certainly less known by the international audience is that, four years before Le Bon's seminal text, Italian criminologist, sociologist, jurist, journalist, and literary critic Scipio Sighele (b. Brescia 1868, d. Florence 1913) had published La folla delinquente: Saggio di psicologia collettiva [The Criminal Crowd: An Essay on Collective Psychology, this volume], to be followed by numerous other explorations of the psychological mechanisms of collective behaviour and the power of social suggestion-among them La coppia criminale (1892) [The Criminal Couple, this volume], La delinquenza settaria (1897) [Sectarian Criminality, this volume], and L'intelligenza

1 Le Bon himself adopts this expression to connote the social situation of the European fin de siècle. For additional discussions of the age of crowds in a broader cultural and philosophical context, see Moscovici, Age, Schnapp and Tiews, eds., Crowds; Bodei, Destini.

2 Beyond France, Charles Dickens's 1841 historical novel Barnaby Rudge is also worth remembering for its gripping descriptions of the frightening mobs in the Protestant anti-Catholic Gordon Riots of 1780. 
della folla (1903) [The Intelligence of the Crowd, this volume]. Born into a politically and socially active family originally from Nago, in the province of Trento, and supporting the Italianness of the region while it was still under the Austrian regime, Sighele grew up in various areas of Italy, owing to his father's frequent relocations as a magistrate. In 1890 Sighele gained a law degree in Rome, under the supervision of Enrico Ferri (1856-1929), a criminologist, politician, and writer who, like Guglielmo Ferrero (1871-1942) and Adolfo Zerboglio (1866-1952) — two other mentors of Sighele's-had studied with Cesare Lombroso (1835-1909), the renowned physician, anthropologist, and jurist considered to be the father of Italian criminology. Sighele taught at the Universities of Pisa and Rome and at the Istituto di Scienze Sociali in Florence, and he held courses in criminal sociology and collective psychology at the Institut des Hautes Études in Brussels. ${ }^{3}$

The title of Sighele's first and best known book, La folla delinquente (1891) [The Criminal Crowd, this volume], recalls, indeed, texts like L'uomo delinquente [Criminal Man] and La donna delinquente: La prostituta e la donna normale [Criminal Woman, the Prostitute, and the Normal Woman] in which Lombroso studied the category of deviance using a descriptive, clinical method. Yet, Sighele distances himself from the Lombrosian anthropometric approach, as well as from his master Enrico Ferri. Shaped by positivist thought, Lombroso interprets social anomalies almost exclusively in physiological and psychological terms, locating the signs of criminal behaviour in the subject's somatic features, and treating the propensity to criminality as a hereditary pathology. For his part, Ferri is more interested in the connection between socioeconomic influences and crime rates, and maintains that, rather than devising punitive methods for criminals, a culture of legality can be established through crime prevention. At the same time, Ferri remains loyal to Lombroso's biological positivism, according to which human behaviour is regulated by a deterministic sequence of causes and effects. Swerving from both his predecessors, Sighele rejects an anthropological interpretation of

3 Details about Sighele's international standing as a lecturer can be found in the archival material of the Fondo Sighele at the Biblioteca della Fondazione Museo Storico del Trentino, especially in the first album, "In memoria del mio Scipio," compiled by Sighele's devoted wife Antonietta Rosmini. Among Sighele's conferences, Rosmini lists ten in Brussels in 1899, one in 1900, eight in 1901, six in 1907, and she highlights his acclaimed talk at the Congress of Criminal Anthropology in Amsterdam on 4 September 1901. 
crime and questions the abstract idea of an integral, rational subject. Sighele realizes that it is not enough to identify atavistic signs of deviance so as to distinguish between normal and anomalous subjects, insofar as individual behaviour can be temporarily altered. Therefore, he investigates the psychological foundations of individual and collective actions at the same time, focusing on the criminal attitudes developing from their interplay in particular social contexts. He conceptualizes an unpredictable multitude that magnifies the conflicting, destabilizing drives latent in the individual psyche, and that emerges as something qualitatively different from a mere sum of self-contained singularities while, at the same time, not coterminous with the idea of society. With Sighele, the crowd itself becomes a distinct and problematic subject, anonymous and chiefless, yet powerful enough to preserve social order or to generate social changes.

Not by chance the group begins to be studied as an agent of subversion worthy of a designated discipline-collective psychology-to which Sighele will devote his entire career. Sighele writes in a newly born Italy trying to negotiate between the patriotic dreams of the Risorgimento and the disappointing reality of the post-unification period. From the unification to the First World War, Italy attempts to achieve political and social stability through inclusive coalitions able to give voice to and at the same time contain very diverse forces, including the growing economic and social power of the middle class; a conservative, nostalgic, pro-Bourbon South; and a mounting popular unrest in response to increasing taxation, parliamentary corruption, financial scandals, and favouritism towards agricultural and industrial oligarchies to the detriment of farm and factory workers. Between 1893 and 1894, after an economic and agricultural depression, the upheaval of the Sicilian "Fasci"-leagues of peasants, miners, artisans, industrial workers, and intellectuals with a socialist, anarchist, and often millenarian orientation demanding social justice in reaction to low wages, exploitation by landowners, and protectionist tariffs-fostered the fast spread of riots in other agricultural and industrial areas of the Italian peninsula. Order was restored with the intervention of the Italian army that escalated to numerous summary executions and extensive arrests targeting association leaders, crowds of protesters, and alleged sympathizers. In May 1898 Milan was the theatre of the socalled Bava-Beccaris massacre, the suppression of massive riots protesting against the rise in food prices. Aggressive group reactions to appalling working conditions had already occurred in previous decades. Violent farmers' strikes in northern Lombardy in 1871 and 1877 were followed 
by more widespread and worrisome episodes in southern Lombardy and Veneto from 1884 to 1886 , which showed the power of socialist and anarchic ideas, and culminated with trials in Venice (Virgilii 6). On 8 February 1889 , a thousand unemployed workers in Rome committed acts of vandalism instigated by some leaders, although, as Sighele himself mentions in The Criminal Crowd, they ultimately regained reason and calm upon the intervention of an armed soldier. Things went differently in the French town of Décazeville, where, in 1886, a group of miners suddenly turned into fierce murderers owing to the "unknown and powerful influence of the crowd" (Crowd 54).

The increase in mass movements-demonstrations, strikes, riots, but also peaceful group manifestations like juries, committees, and theatre spectators-draws the attention of the scientific and juridical community towards collectivity as the social, political, and often subversive subject of modernity par excellence. This new entity demands a reconceptualization of criminalization and of responsibility, and the development of legal answers adequate to the passage from the individual to the group. In this context, between psychology and sociology, Sighele develops an interest in collective behaviour and crime resulting from associative forms of diverse extensions, yet always characterized by complicity as a distinguishing feature.

The scant attention to Sighele throughout the twentieth century and to date is the more surprising given the international visibility of this figure during his lifetime. This came not only as a result of Sighele's participation in international congresses and his recurring teaching appointments in collective psychology and criminal sociology at the Institut des Hautes Études at the University of Brussels, but also because of an intriguing international editorial controversy that the American magazine Popular Science Monthly summarized in the following terms: "Sighele made his name with an admirable book The Criminal Crowd which a French writer has thought fit to appropriate in outline and almost entirely in substance, obtaining for it the honor of translation into English, while the real author has been left out in the cold" (Zimmern, "Criminal Anthropology in Italy" 758). The author of this 1898 article, GermanBritish writer and translator Helen Zimmern, is here referring to Sighele's diatribe against Gustave Le Bon himself-whose plagiarism from Sighele was publicly recognized, as we will see-in contrast to his more cordial relationship with equally renowned French sociologist Gabriel Tarde, who will at least acknowledge Sighele as a precursor. Zimmern's recognition of Sighele's ground-breaking ideas hits the mark, as the widespread echo 
of The Criminal Crowd was also promptly attested by many translations in French, Spanish, German, Russian, Polish, and Dutch; none, however, in the English-speaking world. ${ }^{4}$

The entry of Sighele's works into the anglophone world is hence highly overdue, together with a reappraisal of his writings able to foreground not only his contributions to the domain of sociology and criminology, but also his wider-ranging engagement with broad European intellectual debates on paramount issues that were becoming increasingly relevant to Italy in his time, such as the role of urbanization in the development of criminality, the problematic borders between individual and collective accountability in mass society, the legal and ideological constraints in the education and emancipation of women, the social and institutional challenges to the care and upbringing of children, and the responsibility of literary representation in the relationship between aesthetic standards and ethical norms.

There are also questionable aspects of Sighele's thought that make him a spokesperson of the ideologies of his time-for instance, as we will see, his contradictory approach to gender equality and his resistance to feminism, or his hostility to parliamentarism and his nationalistic overtones. Although far from negligible, once these controversial viewpoints are contextualized within a well-rounded portrait of the author, they can provide a more dynamic perspective on turn-of-the-century Italian and European culture as a transitional period facing the new simultaneously with fear and excitement. Through Sighele's eyes we catch a glimpse of the complexity of modernity, with which Italy was coming to terms as a recently unified nation.

\section{The Italian "Man of the Crowd"}

This old man $[\ldots]$ is the type and genius of deep crime. He refuses to be alone. He is the man of the crowd. [...] I shall learn no more of him, nor of his deeds.

-Edgar Allan Poe, "Man of the Crowd"

4 See Ginneken 83; McClelland 119. Contrary to Chiara Gallini’s assertion (15), there are no English translations of La folla delinquente. Therefore, the reference to Sighele's English title The Criminal Crowd with the date 1894 in McPhail's The Myth of the Madding Crowd (2) is also incorrect. 
According to Georg Lukács, the French Revolution rendered history for the first time "a mass experience, and moreover on a European scale" (The Historical Novel, 23; original emphasis). The multitude's storming of the Bastille comes to symbolize the power of an impulsive collectivity, frightening for its might as much as for its irrationality, but destined to become the protagonist of nineteenth-century European events because, as Lukács argues, the increasingly frequent mass upheavals are no longer perceived as "a "natural occurrence"" (23). Rather, the mass acquires visibility, a consciousness of itself as a "historical character" (23). Indeed, when Sighele begins to write about the crowd, not only history but also literature, even in Italy, has already offered memorable demonstrations of the threatening and at times even bestial behaviour of the masses, from Alessandro Manzoni's I promessi sposi [The Betrothed] and Storia della colonna infame [The Column of Infamy], Iginio Ugo Tarchetti's Una nobile follia [A Noble Folly], and Edmondo De Amicis's La vita militare [Military Life in Italy: Sketches], to Gabriele D'Annunzio's Novelle della Pescara [Tales of My Native Town].

Yet, the crowd also captivated writers for whom the vast multitude of the populace embodied the revolutionary democratic impetus able to bring about social improvement. Karl Marx's utopian proletarian revenge represents the paramount example of a redemptive turning point able to overturn class relationships. Even before The Capital and the civil uprising of June 1848 that put Paris at the mercy of the mob, Jules Michelet (1798-1874) had expressed his messianic vision of the people-a poor, voiceless creature, laborious and despised but, in fact, grandiose and innumerable, ultimately coinciding with humankind itself-in lectures that preceded the more systematic argument of works like his 1847 History of the French Revolution. Likewise, Italian intellectual and political activist Giuseppe Mazzini (1805-1872), who posits a direct link between God and the people as the only synergy able to bring freedom to Italy, forcefully asserts that "nothing now succeeds if not supported by the masses" ("Europe" 455), since, just as "thought is the action of the individual" (456), action is "the thought of the people" (456).

Between the two extremes represented by the brute destructive force of the mob and its redemptive collective might, Sighele places his own vision of the crowd, blending liberal and undemocratic elements. On the one hand, he assumes human multitude's predisposition to commit evil and does not exonerate single individuals from the responsibility for their negative actions as members of a group. On the other hand, however, he admits that legal provisions have to take into account the extent of each participant's involvement, and the reasons for it. The Criminal 
Crowd: An Essay on Collective Psychology remains Sighele's most iconic work, even if it may seem rather succinct and often impressionistic. Its first edition consists, to a large extent, of pronouncements by other European intellectuals with whom Sighele engages. Yet, his pioneering theorization of the crowd as a new criminogenic subject at the crossroads of psychology and sociology had great resonance. As he himself explains four years later in the preface to the second Italian edition (1895), science and tribunals had never before contemplated that the defendant could be a crowd, instead of a single person (Folla II ed., i). Sighele situates himself against the backdrop of previous theorizations of the social dimension, such as romantic readings of peoples as products of a collective soul often determined by race, or organicist interpretations of the social as the result of a progressive evolution from a simple biological entity to a complex, rational collectivity. For instance, Sighele refutes the correspondence between individual and social psychology through which Herbert Spencer (1820-1903) conceptualizes human aggregates as stable constructs made of homogeneous components. Sighele assumes that an aggregate of individuals is different from the sum of the single selves, and that not all collectivities are the same. In the case of "heterogeneous and inorganic" (Crowd 12) groups of people-Sighele's specific object of study - the laws of sociology are for him not applicable and need to be replaced by those of collective psychology, a term he borrows from Enrico Ferri's theory, and further explores.

Therefore, not all the elements in Sighele's argumentation are new, ${ }^{5}$ yet he systematizes them within a new interpretive framework. The Criminal Crowd can be considered an incubator of ideas that Sighele further elaborates in subsequent works, and its relevance can be fully appreciated

5 Although Gallini maintains that it was Sighele who coined the expression collective psychology (17), as we can also infer from The Criminal Crowd (9), in a note following Sighele's correspondence with Tarde, Ferri explicitly acknowledges that he gave that name to the discipline in the second edition of his volume Nuovi orizzonti (1884) and that Sighele made it blossom ("Nota di Enrico Ferri," Folla II ed., 157). Sighele himself substantiates this fact in his response to Ferri, as he mentions his master's "felicitous distinction between collective psychology and social psychology, which was the spark of my book on the criminal crowd" ("Ancora sull'intelligenza e la moralità della folla," Folla II ed., 171). Sighele also explicitly maintains that, while he studied collective psychology, Ferri defined it. Along the same lines, The Criminal Crowd-and most of Sighele's subsequent works-are in dialogue with a surprising array of European sociologists, scientists, and humanists. 
if it is read in connection with Sighele's overall thought. ${ }^{6}$ Only a year after it first appeared, a French expanded version brings Sighele's discussion under the international spotlight. Sighele himself continues to present his investigations as work in progress-given that collective psychology is still "a science in its infancy" (Folla, II ed., i), ${ }^{7}$ and crowd psychology "has just been born" (ii) —yet without overlooking their cogency and cumulative effect, as "logical applications of a single thought and of a doctrine resulting from extensive musings" (Settaria 10). For instance, by assuming that imitation is one of the strongest instincts in human nature, Sighele elaborates on the work of anthropologist and psychologist Giuseppe Sergi (1841-1936) on the reflexive receptivity of the psyche, and on suggestion as its acute phase, ${ }^{8}$ highlighting the gradual shift from isolated instances to the collective, epidemic manifestations of the phenomenon. Likewise, building on the claims of alienists like Giuseppe Seppilli (1851-1939), Henry Maudsley (1835-1918), and Gerard Van Swieten (1700-1772) about the influence of an insane person upon his entourage, Sighele concludes that suggestion is a universal phenomenon that acts in the same way in states of insanity and in normal conditions, reaching its climax with crowd behaviour. ${ }^{9}$ Since emotional intensity increases commensurate with the number of individuals experiencing it in a particular circumstance, suggestion promotes collective crime and combativeness because it instils in each member of the crowd the belief in one's own omnipotence and impunity. Sighele emphasizes that those feelings of self-aggrandizement are not the cause but, rather, the consequence of the emotional contagion that derives from one influential person's instigation, be it a cry, a word, or a bold action. He also adds, however, that a single prompt is not enough to influence a multitude's

6 Furthermore, as Sighele will explain in La teoria positiva della complicità [The Positive Theory of Complicity], The Criminal Crowd was conceived as the first volume of a collection to be titled Le società criminali [Criminal Societies], dealing with biological, sociological, and juridical aspects of collective crime, which would also include The Criminal Couple and Sectarian Criminality.

7 Hereafter, all parenthetical titles in Italian refer to quotations from sections of Sighele's books not included in our volume. English translations are my own.

8 For instance, Sergi, in his 1889 article "Psicosi epidemica" maintains that the suggestion observed in hypnosis is, in fact, a cardinal phenomenon of any individual's psychic life (154). It is so pervasive that Sergi even defines it as "un morbo epidemico di natura psicologica" [an epidemic disease of a psychological nature] (160).

9 It is precisely this all-encompassing power of suggestion as a practically universal, hence almost magical force that Georg Simmel, while upholding the centrality of crowd behaviour, will criticize in Sighele's argumentation, to the detriment of more solid explanations like interaction (see Borch 87). 
behaviour, hence suggestion alone cannot account for the degrading collective manifestations. In the crowd "the microbe of evil can easily thrive and [...] the microbe of good almost always dies" (Crowd 32), because, Sighele concludes, "the good qualities of the individuals, rather than adding up, cancel one another out" (32).

Sighele explains this radical behavioural change through a parallel, which Sergi had already introduced, between suggestion and hypnosis, a captivating phenomenon for turn-of-the-century European scientists from Lombroso to Sigmund Freud (1856-1939), in the wake of the studies by French neurologist Jean-Martin Charcot (1825-1893). ${ }^{10}$ The Criminal Crowd assumes that, just like human personality is not "entirely extinguished, but only diminished" (Crowd 69) under hypnotic suggestion, the impetus of the crowd favours crime even among individuals who are not born criminals, but simply weak. People are "easily or very easily prone to the suggestions of the external environment, according to the cases and degrees" (71). In The Criminal Couple he will reiterate this connection by treating cases of "suggestion in the state of wakefulness" (Couple 87) like those of "hypnotic suggestion" (87).

Together with the references to hypnosis, as well as to other scientific phenomena like contagion and microbial infections, ${ }^{11}$ a recurring simile taken from chemistry (and already adopted by Ferri) highlights the difficulty of ascribing juridical responsibility to the individual members of an assembled group: "just as chemical reactions among various elements result in new and different substances, so, too, the psychological reactions among various feelings result in new and terrible emotions, unknown to the human soul until that moment" (Crowd 37). Sighele's essay Contro il Parlamentarismo [Against Parliamentarism] will foreground "the very complicated laws of chemistry" (Sectarian 198) that govern the human psyche even in political contexts, resulting in "always surprising, and often unexplainable, phenomena that are called combinations and fermentations" (Sectarian 198) — a claim that reappears almost verbatim

10 Freud had referred to hypnotic suggestion since his studies with Charcot at the Parisian Salpetrière Hospital in 1885-86 and started using hypnosis to treat nervous diseases in 1887.

11 Another scientific term that Sighele frequently adopts to describe mass behaviour or the effects of suggestion upon the individual is the verb "to polarize," which we have preserved in our translations, whenever we deemed appropriate, so as to highlight Sighele's multifaceted idea of a certain transmission and accumulation of energy (alternatively connoted in biochemical or electromagnetic terms) characterizing the collective experience. 
in Modern Eve (this volume). Given Sighele's insistence on the unexplainable complexity of a group's conduct,- suggestion is an "arcane force" (Couple 79), as he claims in The Criminal Couple-, his "psychological chemistry" (Sectarian 205) is ultimately closer to alchemy, since, as we read also in The Intelligence of the Crowd, "although the phenomena of collective psychology resemble chemical phenomena a great deal, for their unexpected precipitates [...], what is possible in chemistry is impossible in collective psychology, namely, to know the required dose of the various substances in order to obtain the new substance" (Intelligence 254).

Significantly, although the starting point of Sighele's theory is the intrinsic difference between the behaviour of the crowd and that of the single subject, these ungraspable forces, in fact, undermine both the social order and the individual's coherence. In The Criminal Couple turmoil and fragmentation emerge as permanent factors in the single self. Even a love relationship reveals to us the illusion of spontaneous action. We believe we are autonomous, while "the suggestive charm has already started to act" (Couple 96). Debunking the absolutist aspirations of psychology, hence implicitly also the adequacy of positivist science to account for the complexity of reality, in Sectarian Criminality Sighele admits that all in our world is contradictory, because even a "brief pronoun" like "I" contains "an enormous mystery" (Sectarian 150)—it is a synthesis of our organism, but we ignore its "psychological formula [...] as invisible as air, as impalpable as fire, and nonetheless, as mighty and eternal as life" (150). In these lyrical phrases, which reveal more fascination than uneasiness for this feeling of self-dispossesion, we can see the prelude of the more thorough Freudian investigation that in less than a decade would disclose "the royal road to the unconscious" (Interpretation 608). Significantly, "incosciente" ["unconscious"] as both adjective and noun is already frequent in Sighele's works, although without overt psychoanalytical implications.

As we can see from his correspondence with Tarde and Ferri, included in the second edition of The Criminal Crowd, ${ }^{12}$ Sighele's scholarship had by then an undeniable international relevance, which also entailed an international dispute with Gustave Le Bon. Unquestionably, by the

12 The second edition of The Criminal Crowd reproduces the entire text of the first version, with only minor changes and a slightly longer conclusion. Part II of the volume collects selected correspondence between Sighele, Ferri, and Tarde on the intelligence and morality of the crowd, the physiology of success, and contagion in popular riots, followed by the texts of several Italian court rulings on collective crimes. 
time Le Bon publishes Psychologie des foules, other scholars-among them Taine, Fournial, and Tarde in France, and Sergi, Ferri, and Sighele himself in Italy-had already circulated their theories on group behaviour. Therefore, Le Bon's claim that his book was tracing a furrow "sur un terrain bien vierge encore" [on an almost still virgin soil] (Psychologie 10) sounded rather suspect, especially once Sighele's ideas became even more accessible through the very successful French translation of The Criminal Crowd. In his detailed account of this quite intricate affair, Jaap van Ginneken has convincingly documented, in chronological order, Sighele's interaction with Tarde on matters of crowd psychology and collective crime, the existence of French reviews of Sighele's The Criminal Crowd even before its French translation (followed by even greater visibility in French journals after his translated edition), and Tarde's appropriation of Sighele's research for his presentation at the Third International Congress of Criminal Anthropology in Brussels in 1892, which he frankly acknowledged (Ginneken 119-21). All this intriguing background makes Le Bon's obliviousness rather puzzling. As has been observed, although Psychologie des foules tackles the same subjects as Sighele's, Le Bon does not mention Sighele's treatment of the crowd's crimes, yet, in fact, he produces very similar argumentations, often corroborated by the same examples from previous scholars-the critic and historian Hippolyte Taine (18281893) among them (Ginneken 122; Palano 348). The resentment that Sighele expresses in his article "Una pirateria letteraria" [Literary piracy] is hence justifiable. Among the different forms of crime that he analyses, he cynically places intellectual theft substantiating it with the case of "Mister Gustave Le Bon [...] who [...] copied all or almost all that could be copied from an Italian book titled The Criminal Crowd ("Pirateria" 171) forgetting to cite the author's name. In Sectarian Criminality, Sighele resumes his polemical references to Le Bon's theft of intellectual property, sarcastically adding that, given that one appropriates what is considered accurate, Le Bon's plagiarism attests to the validity of his own observations on the psychopathology of the crowd.

In Psychologie des foules, however, Le Bon also takes a different direction, offering a new explanation for the behaviour of both occasional collective formations and entire peoples or races. Where Sighele focuses on the leader's influence upon the mass, Le Bon emphasizes two factors on which the psychological structure of a collectivity depends, namely, beliefs and opinions. While beliefs are deeply ingrained in a civilization and can only be modified with violent revolutions, opinions for Le Bon are fleeting standpoints that a crowd occasionally endorses (Psychologie $132,179)$. Yet, since he foregrounds the mainly religious nature of the 
crowd's beliefs, Le Bon, like Sighele (and in contrast to Lombroso) assumes that any form of group behaviour derives from an irrational, emotional force. In any case, the tension between their respective standpoints seems to dissipate from the perspective of Sigmund Freud who, in Group Psychology and the Analysis of the Ego (1921), despite his extensive discussion of Le Bon's "deservedly famous work" (Group 11), adds that "none of that author's statements bring forward anything new" (32), and that, in particular, the idea of "the collective inhibition of intellectual functioning and the heightening of affectivity in groups, had been formulated shortly before by Sighele" (32). Yet, Freud is ultimately more focused on what both Sighele's and Le Bon's approaches share, namely, their attention to "groups of a short-lived character, which some passing interest has hastily agglomerated out of various sorts of individuals" (35). For his part, Freud upholds the continuity between individual and group, interpreting suggestion and emotional contagion as particular manifestations of a more elementary and universal force-the libidotranscending the specific kind of group.

The Criminal Crowd well shows the occasional nature of the group that Freud criticizes in Sighele and his contemporaries. Here the unpredictable outburst of mass brutality derives neither from a conscious intent to revolt nor from its leader's genetic predisposition to criminality. Rather, in Ferri's footsteps, Sighele explains mass behaviour as a transitory state that, because of external perturbations, alters the ordinary social equilibrium and the individual's psychic stability. Sighele, however, conceives the mind as a progressive superimposition of psychic layers, implying that any episode of collective emotional turmoil occurs because suggestion brings back to the surface the most ancestral elements inherent to the individual and the species as a whole: the crowd "descends with a dizzying speed down the rungs that lead it to the most cowardly brutality" (Crowd 49), hence suddenly exposing "the savage [...] from underneath the skin of civilized man" (39). This account of the evolution and relapses of civilization into savagery is one of the recurring themes in turnof-the-century intellectual discourse, itself evolving from the depiction of atavism as an endemic, regressive force that threatens to disaggregrate civilization-as in Taine and Lombroso-, down to Nietzsche's evocation of ancient, noble roots as the model for future regeneration. For his part, Freud will reinterpret atavism not only as dormant relics of destructive primitive instincts brought to the surface by the individual's group experience, as in his Group Psychology and the Analysis of the Ego, but also as a productive anachronism that, by manifesting the disruptive relationship between the modern subject's traumatic past and its present mental 
and behavioural distress, fosters self-awareness (in the episode of the Wolf Man, for example). Arguably, Sighele partakes of both these perspectives, because, although he sketches a negative portrait of the crowd, he also maintains that the crowd promotes social change.

Sighele's interest in group behaviour soon transcends the mere dichotomy between individual and collectivity and begins to focus on specific social associations that become the object of The Criminal Couple and Sectarian Criminality. Elaborating on his previous observations about group suggestion as the extension of the delirium à deux, Sighele now justifies his focus on couples as the opposite extreme of the criminal crowd: "the crime by two and the crime by a thousand [...] close the chain of all the innumerable varieties and forms of criminal societies" (Couple 76). As the most elementary form of group association and supposedly the embryonic stage of all other more complex alliances, the couple allows Sighele to further explore the dynamics leading to the individual's influence on the mass, be it for legal, illegal, or criminal activities. While The Criminal Crowd discusses crowd behaviour as a temporary condition that may affect anyone, hence representing a mitigating factor in the individual's responsibility, ${ }^{13}$ The Criminal Couple narrows its focus to unhealthy social environments where particular categories of subjects commit crimes as a couple. Resuming his earlier discussion of the power of suggestion, Sighele establishes a correspondence between physiological and pathological behaviour, maintaining that the captivating power that a notorious murderer exerts on a criminal is analogous to that of a charismatic artistic or scientific figure on a normal individual. Both respond to the need for an ideal, be it glorious or infamous, and made further attractive by the ascendancy that these models can have on those who are in direct contact with them.

Sighele's criminal couple functions according to a kind of Hegelian master-slave dialectics that highlights the asymmetry and simultaneously the interdependency between the two parties. ${ }^{14}$ Just as the cohesion of two people in love derives, for Sighele, from a conscious or unconscious

13 An English summary of Sighele's support of penal leniency on unpremeditated mob criminals, penned by Robert Ferrari, appeared as "Sighele on Adulteration of the Positive Doctrines in Collective Crimes" in a 1912 issue of the Journal of the American Institute of Criminal Law and Criminology.

14 Significantly, Sighele himself alludes to the interdependence of master and slave in his analysis of Balzac's Human Comedy when he describes the criminal couple represented by Vautrin and Lucien de Rubempré (In Art and in Science 405). 
negotiation between the superiority of one person and the submissiveness of the other, the wicked individual and his morally and intellectually weak counterpart are reciprocally enslaved. As it creates a spiritual and intellectual dependence between the two, this apparent imbalance enables "magnetic communications from soul to soul (Couple 93). The visceral syntony caused by unconscious reciprocal imitation can easily propel both constructive and destructive emotions, and lead to homicide and even suicide, which, according to Sighele, are often committed by the weaker individual under the influence of the more compelling partner. Although Sighele considers insanity to be the cause of social alienation par excellence, he maintains that even the insane couple is held together by this intimate social bond between what he presents as the succubusthe person who instigates-and the incubus - the individual subjugated to the partner's influence..$^{15}$ Upon these premises Sighele substantiates "the universality of the form à deux of suggestion" (89) and shows the path that transforms mere diversity of personality into criminal suggestion, according to a tug of war between corrupting and being corrupted that does not diminish either partner's moral and legal responsibility. If "[u] nity is strength in good as well as in evil" (143), a crime committed by a couple is more serious and deserves harsher punishment.

Assuming the lack of intrinsic difference between the born and the occasional criminal-in contrast to Lombroso-, Sighele illustrates a series of cases in which suggestion influences a couple's crime, blurring the emotions and the degree of accountability of the two individuals, and maintaining that the subject is neither completely manoeuvred by forces beyond its control nor totally autonomous in its decisions. From the murderous lovers to the infanticidal couple, he thus throws light upon social, legal, and moral challenges in Italy and Europe overall at that time, for instance, the increase in abortion cases in urban environments and the need to address male complicity and liability. At the same time, however, Sighele falls back to the positivist Lombrosian rigidities as soon as he

15 Sighele already introduces the terms succubus and incubus in a note to The Criminal Crowd (26n58) where he connects the effects of suggestion in normal and insane states, as well as in suicide and crime, also explicitly associating the condition of the succubus to that of a slave. Significantly, in the 5th edition of his L'uomo delinquente (1897), Lombroso quotes extensively from Sighele in his discussion of the criminal couple as an instance of occasional crime committed by "criminaloids," that is, individuals predisposed to crime but carried away by circumstances-in this case by reciprocal suggestion. 
confronts the anomalies and excesses of what he defines as degenerate couples, a veritable "other" reality with respect to social norms. From prostitutes and their pimps to same-sex partnerships, Sighele highlights what for him are dangerous psychological perversions through which allegedly unhealthy social components threaten healthy and righteous individuals.

The wider group associations mentioned at the opening of The Criminal Couple become the object of investigation in Sectarian Criminality, which Sighele conceives as the trait d'union between his study of the crowd and that of society at large. Referring-this time in peaceful terms-to Le Bon's latest studies on crowd psychology, together with contributions by the only two other scholars whom Sighele recognizes in the field, namely, Henry Fournial (1866-1932) and Gabriel Tarde, Sighele here reinterprets the dynamics of collective criminality beyond the simple reemergence of violence as a temporary halt of, or deviation from, human evolution. Sighele now distinguishes between the atavistic brutality of lower social layers and the perverse deviance of more elevated classes, claiming that the former constitutes one particular stage of the evolutionary process- "the crisis of a young organism that is growing and progressing" (Settaria 24), hence is the intimation of renewal, the dawn of a new social era-, while the latter is a pathological manifestation confirming that the current social system has reached its terminal phase, "the index of a sunset, [...] a sign of the degeneration of an already old organism" (24). As it manifests the energy and boldness with which lower classes can prevail upon a superior but exhausted social layer, the crowd's psychological dynamics substantiates the widespread anxiety that perturbs the turn of the century, "that obscure complex of causes that the French define as fin de siècle, Nordau end of race" (20) and Sighele "less poetically, but more realistically-end of the bourgeois regime" (20, original emphasis). This observation about the fragility of the apparently monolithic, rational, self-controlled bourgeois subject, the protagonist par excellence of the European late nineteenth century, is particularly insightful in connection with the social dynamics of post-unification Italy, where the Italian subject, and the bourgeoisie in particular, were in their nascent state. As Susan Stewart-Steinberg observes, the national subject that emerges from the project of making Italians is "an ego of anxiety" (Pinocchio Effect 4) living in a post-liberal environment. Where exactly does Sighele situate himself in this vision of a conflictual European society allegedly on the verge of implosion? What future does he delineate for the Italian mass society approaching the new century?

With an interesting conflation of space and time, Sighele assumes that every society reproduces synchronically its own diachronic evolution. 
Hence the alleged savage tribes that constitute for him the primitive ancestors of advanced civilizations reappear as the lowest classes within modern societies. Anything but neutral despite his declared objectivity, this social layout conveys Sighele's own judgment and fears as he attempts to shake the middle and cultivated class from its indifference to the looming social threat. Inspired by the Goncourt brothers' depiction of workers' crowds as the barbarians of modern society, Sighele here underscores, but does not endorse the renewing effects of their disruptive potential. Rather, through the study of collective psychology, Sighele pursues at once a criminological and a social objective, namely, to understand the illness of civilization and to find remedies. Yet, the predominant feeling that emerges from his argumentation is a sense of belatedness and of an impending defeat at the hands of "the future wreckers of our civilization, or-at least-its future masters" (Settaria 45). If the power of masses constitutes the only invincible and increasingly respected force that holds the destiny of the world in its "unconscious hands" (43), the only resource left to withstand such an ungovernable entity is to use knowledge as a protection against the danger of being too much governed by it.

With his intellectual work, Sighele therefore now strives to fill the many persisting gaps between crowd psychology and sociology, examining other forms of group psychology that are for him necessary to understand such an apparently dangerous social movement that, however, also constitutes an inevitable step in social evolution. For instance, he presents the modern state as the ultimate and most perfect human aggregate that developed out of the primitive and savage crowd, transforming the latter's transitory and unconscious scope into a stable organization of individuals. In overtly Darwinian tones after his influential reading of On the Origin of Species, Sighele explains the evolution of other intermediate associations-sects, castes, and classes-which he defines as homogeneous and permanent in opposition to the heterogeneous and occasional social formations examined in The Criminal Crowd. The sect is crucial for Sighele, as it represents the "nucleus and the yeast of every crowd" (Sectarian 151), "the chronic form of the crowd" (Settaria 55), just as, conversely, the crowd can be seen as "the acute form of the sect" (55). When individuals of different social extraction or education share a common ideal generated by religious, scientific, or political faith, they acquire remarkable compactness and power. No matter whether it is composed of criminals, martyrs, or instigators, the sect-Sighele argues-always represents the first phase of the development of an idea, which requires a unique rule and scope in order to consolidate itself. 
Because of its total devotion to an ideal, the sect's actions are never impulsive. Even when it resorts to violence, it does not commit unnecessary atrocities, unlike the crowd. At the same time, with respect to castes and classes, the sect is "always innovative" (Sectarian 173) because, thanks to the psychological strength and unity of its members, it nourishes a spirit of revolt that, aiming at social dissolution, promotes renewal. The sect is hence the negative soul of any revolution, necessary as much as its crimes, despite its "inferior and retrograde tactic" (170), and Sighele prides himself on being the first to demonstrate the utility of political crime for human progress.

Yet, Sighele's apparent endorsement of social unrest as a factor of innovation coexists with a deep uneasiness at the individual's increasing lack of autonomy. The potential mobility between different kinds of human association confirms with a vengeance what Sighele presents as the crisis of the subject, overthrown by multiple forms of collectivism. Elaborating on his recurring thoughts about the constraints of the self, Sighele here effectively maintains that the "poor human brain" (Sectarian 149), deprived of free will, is no longer "an absolute king" (149), but, rather, "a constitutional king" (149), with only a semblance of freedom and, in fact, subject to a plurality of external factors, fermenting in his brain and awakening simultaneously. Significantly, even the sect leader, who apparently exerts his authority on the group's thoughts, is, in fact, subordinated to the influence of the idea itself. The “meneur [...] is, above all, a ménê" (159). Possessed by fixed ideas, he no longer belongs to himself-an effective image of self-alienation with which Sighele synthesizes the subject's lack of control over the influence of the multitude-what Remo Bodei connotes as the colonization of consciousness (Destini 12).

Furthermore, just as collective psychologies change according to the particular social aggregate, morality differs not only among individuals of various epochs and social environments, but even within a single subject in relation to its roles and conditions. In particular, building on his conviction that collectivity is always morally worse than a single agent, Sighele elaborates on the difference between the malleability of public moralities (deliberately in the plural) and the greater rigidity of individual morality. Sectarian morality foregrounds the centrality of cultural and conceptual borders in determining moral resolutions, as the sect highlights the dualism between internal and external relationships, and consequently, the relativity and arbitrariness of moral codes. Hence patriotism, which Sighele considers no less sectarian than a religion, shows how easy it is for the cult of love inside the homeland borders to turn into 
a religion of hate against what lies beyond them. ${ }^{16}$ Likewise, the equally sectarian political morality arbitrarily justifies governmental corruption, a particularly hot topic in Sighele, which, as we will see, nourishes his hostility towards parliaments. ${ }^{17}$

In Sectarian Criminality Sighele reiterates the inevitable discrepancy between public and private morality, and presents history as an incessant struggle between inferior classes, which fight with barbarous means to promote change from below, and superior ones, which, with more civilized strategies, set obstacles from above to slow down progress. Nevertheless, in The Intelligence of the Crowd Sighele transcends the destructive action of belligerent crowds, maintaining that, as a legacy of the nineteenth century, the "multiform and complex" (Intelligenza 17) collective soul already holds the destiny of society in hand, and its power now manifests itself even in peaceful circumstances-as meetings, elections, and public opinion. He hence aims to devise ways to render this despotism "more conscious and worthy" (16), by elevating it morally and intellectually.

Sighele contextualizes his discussion of the collective social dimension within the Italian unification process, offering a critical view of that redemptive notion of "the people" that propelled the Risorgimento. A comparison with other modern European nations shows for him that the proverbial creativity and resilience of the Italian individual has failed to translate into a prosperous common homeland. This Italian psychological paradox, according to which better elementary components generate a much worse product, derives, in his view, from the endemic fragmentation of the peninsula. While France, Germany, or England fostered

16 These statements provide a more nuanced image of Sighele than that of a fanatic nationalist.

17 See section 4 below for a discussion of Sighele's Against Parliamentarism. In Sectarian Criminality, Sighele mentions the scandal of the Panama Canal to demonstrate how honest people can give in to political vice and crime losing any restraint when they participate as a collectivity. The main reason why the affair was denounced, in his view, is that the dealings were not successful, while the politicians involved in the analogous case of the Suez Canal were acquitted. Sighele decries the same imbalance between private and public morality in Italian politics. For instance, he was deeply struck by the political-financial scandal of the Banca Romana that impaired Italy's stability. The bank had loaned large sums to property developers but was left with huge liabilities when the real estate bubble collapsed in 1887. Fearing that publicity might undermine public confidence, Prime Minister Crispi tried to keep the information secret but the scandal broke out in parliament in 1892. 
cohesion of individual energies towards a great collective soul able to inscribe the national character into each single component, Italy has remained a cluster of independent planetary systems, in which regional bonds prevail and every individual bears above all "the stigma of his province" (Intelligenza 20). Yet, the real problem, for Sighele, lies in Italy's disavowal of its own anthropological and psychological variety, and in the false patriotic rhetoric that has ensued. Unmasking the alleged lies on which Italy has been feeding since 1870, Sighele maintains that his country cannot achieve authentic unity through a uniform educational, political, and legal system. The prejudice of this unnatural and impossible evenness can only create "a single Italian type that does not and cannot exist" (22), while, in fact, an administrative federalist system would for him facilitate the development of different kinds of Italian subjects able to shape Italy as a flexible organism harmoniously combining their various energies.

Convinced that the real strength of his country lies outside the atrophying effect of national institutions, Sighele urges a more practical and modern mass education rather than bookishness, so as to foster the birth of "a free and unconstrained people" (Intelligenza 29) endowed with a veritable collective consciousness. Sighele here seems to retrieve but also revise Mazzini's claims on the end of the epoch of the individual, replaced by the modern "mondo sociale" [social world] (Mazzini, "Pensieri" 98; original emphasis). While Mazzini's insistence on the need to educate the people starts from the belief in the latter's edifying potential, Sighele's multitude is never intrinsically good and reliable. Even when Sighele gives credit to collective works, he does not question that, generally, "the crowd is morally worse than the individual" (Intelligence 226), although he admits that sometimes the former surpasses the latter and displays the highest human qualities. We see this duplicity-the obscure, "mysterious divinity of the collective soul" (Intelligenza 33)—in Sighele's treatment of the relationship between art and the crowd and in the role of public opinion.

Sighele reconsiders even the apparent incompatibility between art and the crowd, from a standpoint that recalls Oscar Wilde's maxim, "Art should never try to be popular. The public should try to make itself artistic" (Wilde 248). Discussing the strife between individualism and socialism, which for him is one of the many tensions that nourish "the great doubt" (Intelligence 223) into which the new century is born, Sighele challenges the contrast between the haughtiness of the artist and the faithfulness of his crowd of followers, highlighting the "unconscious work" (223) of collective production. Despite the frequent Nietzschean 
overtones in his overall oeuvre, ${ }^{18}$ here Sighele goes as far as to attack the "supermen" (233) who despise the multitude as a jumble of brutes unworthy of the gift of a work of art. Rather, the genius reveals truths that, in fact, are asleep in everybody's consciousness and that the collective soul has only partially sketched or glimpsed but will ultimately embrace with time, as any idea has to struggle against adversity before imposing itself and gaining collective approval. Having bridged the gap between crowds and society, as much as between the individual and the collective mind, Sighele transcends the stigma of the multitude univocally as an agent of crime and, rather, validates its positive, constructive role as a contributor to civilization and as a producer of culture, in competition with single great figures for the advancement of progress (McClelland 172).

By redeeming the intellectual function of collectivity, Sighele now paves the ground for his discussion of public opinion, focusing once again on the ambivalence of the multitude as a whimsical supporter of error much more frequently than of truth. Sighele's investigation of the notion of "public" as a synonym of either crowd or people according to the context owes to the categories that, more than a decade earlier, Gabriel Tarde had discussed in articles he would later collect in L'opinion et la foule (1901). For Tarde, after the psychology of the crowd it was time to study the psychology of the public, to be interpreted not so much as any static assembly like the audience at a theatre performance (for him still an instance of crowd), but rather as an endlessly growing collectivity composed of physically separated individuals brought together by a mental cohesion. ${ }^{19}$ Endorsing Tarde's main standpoints and terms on communication and social influence, Sighele invokes the positive method to separate the vague and protean nature of the public from other collective entities, like the crowd or the people in general. The crowd requires physical contact, but the public - a more advanced form of association

18 In addition to several references to Nietzsche in his books, Sighele authored the essay "Nietzsche e le teorie biologiche moderne," which appeared in his posthumous collection Letteratura e sociologia. There, he maintains the Lamarkian and Darwinian foundation of the German philosopher's thought, explaining the theory of the superman as "a logical consequence of evolutionary transformism" (34).

19 "The public [...] is a dispersed crowd, in which the influence of minds on one another has become a remote action, at increasing distance. Ultimately, Opinionwhich results from all those remote or direct actions-is for crowds and publics what thought is, somehow, for the body" (Tarde 7, my translation). "We have made the psychology of crowds; now we have to work at the psychology of the public, [...], as a purely spiritual collectivity, a dissemination of physically separated individuals, whose cohesion is entirely mental" (8-9, my translation). 
from the evolutionary point of view-is comprised of people who share an idea or common feeling, thanks to an "invisible, mental cohesion" (Intelligence 240). With an argument that anticipates Benedict Anderson's observations (Imagined Community, 39-46) on the role of print culture for the construction of the nation as an imagined community, Sighele connotes reading as an "invisible, intellectual thread" (Intelligence 242) binding individuals unknown to and distant from one another-a much more effective and up-to-date representation of universal suffrage than parliament, Sighele provocatively adds. Unlike the crowd, the public does not necessarily react in unison, even though, Sighele admits, new means of communication like the railroad, telegraph, and telephone are beginning to transport thought more efficiently, providing the public with the unity of time that it lacked.

Yet, the press and other media also allow the meneur's voice to spread more extensively, hence multiplying the forms of suggestion. Significantly, as Sighele draws attention to the complex social structure of his time, he pinpoints interesting situations that transcend the standard succubusincubus polarization. Do newspapers and journalists shape the public or vice versa? Sighele concludes that no single individual, however great, can influence the collectivity. The two parties develop out of a particular social and cultural conjuncture. In so doing, Sighele questions the clearcut, qualitative difference between the discerning abilities of cultivated and uncultivated publics. As shown by the Dreyfus affair in France and by the Italian reactions to Prime Minister Antonio di Rudini's colonial policy after the Adwa debacle of 1896, the majority, no matter how educated, may be wrong, and public opinion can impose itself even without consensus. Therefore, even the apparent distinction that progress has enabled between a barbaric, atavistic crowd and a civilized, modern public can vanish. Just as the most brutal mob can perpetrate murder, the public can inflict insults and commit defamation, which Sighele considers a moral murder. Sighele thus concludes that, in order to understand the formation of public opinion, it is imperative to combine the psycho-physiology of the public with that of the crowd that he delineated in earlier works.

Distinguishing his perspective from both Le Bon's monolithic categorization of the age of the crowd and Tarde's equally static age of the public, Sighele defies univocal standpoints by defining his time both the age of the publics and the age of the crowds. Civilization may as well have transformed the crowd into the public, but the public reverts to its atavistic crowd stage when it can no longer contain itself, just as civilized individuals at times may regress to barbarism. It is precisely to the public that Sighele turns at the outset of the new century, after abandoning his 
criminological interest in the crowd to embrace an intense journalistic activity through which he popularizes the most crucial sociological and psychological issues that were animating contemporary Italian intellectual debates-in particular, the status of women, the impact of feminism on gender relationships, the bleak conditions of children, and the challenges of early childhood education.

\section{Eve's Unconscious Power: Woman's World between "Folla" and "Follia"}

[...] This Hydra with one thousand heads, of sublime altruism at times, quite often of frightening ferocity, and always little responsible for her actions.

—Letteratura tragica, 191

If the behaviour of the multitude, albeit inferior to the individual's, can as easily attain high ideals as it can degrade to savagery, for Sighele, this is because of its contradictory and extreme psychology. For its inability to keep emotions and reactions under control, the crowd is ... a woman, because, precisely like a woman, it is "capable only of excesses" (Intelligence 226), as prone to abnegation as to ferocity, but almost never mediocre and measured in her feelings. Whether Sighele refers to collective resurgences of mankind's buried past or to an overt present, where even the more civilized public opinion has an "undefinable" and "elusive" (234) character, he not only posits a binarism between Western civilization and its external cultural alterity-the savage, tribal, primitive world-but also reinforces this hierarchical comparison, so widespread in fin de siècle discourse, with a gendered simile. The crowd and woman as interchangeable entities embody modernity's internal "other," whom Sighele connotes as endowed with a tremendous unconscious power that they cannot manage by themselves, and that is hence tragically dangerous to social equilibrium.

Whenever woman does not comply with the two roles endorsed by a patriarchal society, namely, the subservient wife and the fertile mother, she becomes the embodiment of the wild, insane unruliness that qualifies the crowd's "negative, destructive action" (Settaria 44). She is thus degraded to her biological function of "femmina" (Intelligenza 14). Likewise, "the crowd is never a spouse or a mother; it is only a female" (Settaria 43). No matter how terrible and immense, neither crowd nor female, can produce on its own, hence they both require to be controlled by knowledge. 
Just as through the study of mass psychology Sighele strives to develop a defence against the future masters and destroyers of modern civilization, the exploration of the female subject reveals his anxiety vis-à-vis this disquieting new social agent and his attempt to prevent practices that overstep the codified expectations of a male-dominated society. The female lack of moderation already appears in The Criminal Crowd, where Sighele mentions women who purportedly surpass their male counterparts in audacity and cruelty during the French Revolution. Curiously, even the political assembly of the Italian parliament is for him "psychologically a female and often a hysterical one" (Sectarian 211) - a derogatory connotation that recurs in subsequent works specifically devoted to woman's condition, such as La donna nova (1898) [The New Woman, this volume] and Eva moderna (1910) [Modern Eve, this volume].

Sighele lives in the most eventful decades for the emergence of the woman question. Although support of women's emancipation develops more slowly in post-unification Italy than in other European countries, in 1868 Gualberta Alaide Beccari (1842-1906), a social reformer and spokesperson for women's rights, had launched the journal La donna, which for decades promoted progressive ideas also abroad through translations of its articles in one of the first British feminist journals, The Englishwoman's Review. Among the contributors to La donna was activist Anna Maria Mozzoni (1837-1920), the founder in 1881 of the League for the Promotion of the Interests of Women [Lega promotrice degli interessi femminili], and a strong advocate of a reform of the laws regulating prostitution, to whom Sighele often refers in his writings. Other associations were soon created in favour of women's civic and political rights, such as the Association for Women [Associazione per la Donna] (Rome, 1897)-soon to become the National Association for Women [Associazione Nazionale per la Donna] - , the National Female Union [Unione femminile nazionale] (Milan, 1899), and the National Council of Italian Women [Consiglio Nazionale Donne Italiane] (1903). Cultural and social initiatives, however, in favour of female advancement clashed with male intellectuals' widespread resistance to innovation, in the name of the stereotypical image of the submissive, romantic, maternal, family-oriented woman. Giuseppe Sergi's 1898 article "Il movimento femminista" effectively synthesizes this struggle. Precisely in compliance with nature's norms and normality, he strenuously defends woman's "supreme ministry" (5) as "mother and lady of the house" (5) and condemns the feminist agitators as dangerous rebels against human nature, who are marked even physically by alleged anomalies that render them incompatible with their mission. The outset of the new century does not entail a radical change of 
mentality, if we think of Filippo Tommaso Marinetti (1876-1944) and his declared contempt for women and hostility to feminism since the 1909 Founding Manifesto of Futurism (Futurism 51), or even Luigi Pirandello (1867-1936) and his critique of women's emancipation in "Feminismo" (Saggi 1068-72). Precisely like the two male protagonists in Pirandello's essayistic novella, Sighele expresses the masculine fear of female independence with often contradictory statements.

Sighele's writings contribute to the intellectual debate on women and feminism by blending ideological clichés like the feminization of violent collective behaviour with the analysis of woman as a new social subject worthy of enfranchisement. Sighele's endorsement of woman's need to overcome the status of savage instinctuality typical of the crowd attests not only to the sociologist's progressive views, but also to his desire to tame the fair sex, putting it in the service of social stability. Therefore, he often sanctions the less threatening female aspirations while he opposes the more problematic and transgressive ones. The feminine world becomes the receptacle of the main stereotypes and ambivalences in Sighele's thought. Yet, from Sighele's diverse reactions across time, we can also measure the impact of the social, cultural, and political questions of which woman becomes a protagonist between the two centuries.

In The New Woman, where, with his customary approach, Sighele draws individual and collective psychological features from pathological manifestations, the female mindset reflects a "psychology of extremes" (New Woman 266) that renders woman either "awful or excellent" (266), "more cynical, more cruel, more brutal, and more depraved than man" (266) and simultaneously able to surpass men in virtue and moral greatness. The cause lies, not surprisingly for an avowed positivist, in her environment. Does this evaluation aim to challenge or to consolidate woman's current status? Sighele maintains that the morally and intellectually narrow space where woman can act-the family-only allows her to concentrate her affectivity on her next of kin, instead of stimulating her brain with broader issues and theoretical discussions. Even woman's greater capacity to withstand pain derives, in Sighele's view, from her lower sensitivity than man's, ultimately confirming the scientific verdict that "woman is of lesser anthropological value than man" (272, original emphasis). ${ }^{20}$

Therefore, Sighele's argumentation at this stage of his career is anything but a denunciation of female alleged inferiority. By granting more

20 Not accidentally, these are truisms endorsed by numerous nineteenth-century intellectuals, from Schopenhauer to Nordau and Weininger, to whom Sighele refers rather frequently in his writings. 
freedom and opportunities, female emancipation for Sighele would erase all gender differences apart from the physiological one, which would not suffice to preserve male attraction to the other sex. Sighele patronizingly co-opts even factual observations like woman's lack of autonomy in order to legitimize man's authority. For instance, man's institutionalization of marriage, despite its often inflexible laws, is for Sighele a great advantage for woman, since it protects her from the danger of free love and of loneliness and misery in old age. Furthermore, physiology accounts not only for the codified contrast between female and male behaviour, but also for allegedly more worrisome female anomalies-veritable "perversions" (Donna nova 81; original emphasis) such as the gender-neutral spinster ["zitella"] (46) or the immoral "half virgins" (48).

To be sure, such aberrations can suffice to dismiss Sighele's position altogether as reactionary and biased, but they also show the difficulty of adjusting to the remarkable changes that were undermining deeply ingrained Italian customs and expectations, partially a result of the influence of more socially advanced Western nations. In the mutable contemporary woman, it is impossible to recognize the woman of yesterday-Sighele asserts with considerable uneasiness. Through his ideological refractions we can glimpse not only the crucial issues with which Italian society was already grappling, but also the developments looming on the horizon. As in the case of the power of crowds, Sighele reluctantly acknowledges the centrality of the so-called woman question in the intellectual discourse of his time and above all woman's expanding social conquests, although he defers them to an undefined future or to foreign cultural spaces, especially England or France. ${ }^{21}$

With the same ambivalence, his 1910 volume Eva moderna [Modern Eve, this volume] expands on a discussion that Sighele initiated in an eponymous chapter of The New Woman, contributing to the widespread

21 In the last chapter of La donna nova, after acknowledging more progressive foreign manifestations of female freedom such as French and German associations for the defence of women's rights or New Zealand women's brilliant performance in public administration, Sighele lingers on two milestones in the lives of American women, namely, the right to vote in presidential elections and the practice of divorce. Wavering between recognition of feminism as a worthy cause and condemnation of it as a pathological deviation that is even gaining ground in stern England (198), Sighele reduces the new woman's subversive impact by defending the solidity of marriage in Italy and by strategically projecting the need for reforms to a vaguely near future able to accommodate the claims of women. 
turn-of-the-century co-optation of the archetypical figure of Eve as the model of modern femininity that synthesizes the major ideological tensions on the woman question. ${ }^{22}$ Censoring feminists' obsession with the sexual problem, which has allegedly degraded "woman" to "female," Sighele extols woman's nobler desire for freedom predicated on the conquest of the rights of the soul in addition to those of the body, but he confines woman's demand for love to her institutionalized domestic roles of spouse and mother, assuming her indifference to multiple lovers.

Much of Sighele's patriarchal argumentation about women is founded upon the triad of imposed social functions-mother, virgin, prostitute-that contemporary French feminist critic Luce Irigaray challenges precisely because it reinforces an androcentric economic network of gender relationships that commodifies women: the mother represents use value, the virgin exchange value, and the prostitute both of them ("Women" 186-87). Sighele attempts to lay bare this biased system of values, yet predictably, he does not go so far as to subtract woman from the mercantile logic of patriarchy. He presents virgins and prostitutes as excessive, but interdependent contributors to a system of sexual production, whereby, while the former category of workers is on strike, the latter has to work twice as much. Attention to the female status on the market of values emerges, for instance, in his critique of Alexandre Dumas's three female categories of vestal, matron, and courtesan (Eve 299), where he presents virginity as a negligible good that becomes valuable only when it begins to circulate through marriage. Sighele, indeed, seems to foreshadow Irigaray's polemical argument when he denounces that men enjoy "this value that marriage has circulated" (37, original

22 From an equally contradictory standpoint, the internationally known physiologist and anthropologist Paolo Mantegazza had also extensively discussed the biological and social role of the "daughters of Eve" in works like Fisiologia dell'amore [The Physiology of Love] (1873) and Fisiologia della donna [The Physiology of Woman] (1893). He glorified the feminine unconditional disposition to give love, which renders women superior to men in the emotional domain, and simultaneously considered women inferior creatures because of their sensitivity, seen as an impediment to their intellectual development. Likewise, Mantegazza denounced social and educational inequalities between the two sexes, yet he opposed all those opportunities that, by promoting women's emancipation, risked compromising the female figure as "the true and great priestess of love" (Physiology of Love 226). See N. Pireddu, "Paolo Mantegazza: A Scientist and His Ecstasies," 23-29. Sighele explicitly refers to Mantegazza in The New Woman (274). 
emphasis), while, in fact, maidens, too, should have the right to free love before, and even instead of, tying the knot. Yet, Sighele implicitly legitimizes the status quo as he ultimately admits the family and society's resistance to such a hypothesis, and thus opts for the lesser evil, namely, the chance to dissolve marriage through divorce rather than the prospect of woman's total freedom through the abolition of the marriage contract altogether. ${ }^{23}$ Not surprisingly, this argument, which Sighele was also repeatedly upholding in public lectures, had already stirred polemical reactions among Italian feminists, as shown by philosopher and jurist Teresa Labriola (1874-1941), who in her 1907 piece in Rivista di Roma writes, "Scipio Sighele concluded with an invocation to the eternal flame-love-, which must spring from the female soul. But please tell me, readers, is it possible to limit woman's psychic life [...] to love alone?" ("Cronaca" 49, my translation).

Sighele's reticent openness to the customs of the modern Eve also characterizes his approach to the question of adultery. It is for him a blatant example of gender inequality at the time, insofar as it was accepted for men but condemned for women. On the basis of his positivist observation of facts against idealism, Sighele supports adultery as a right for both sexes, yet once again, with many caveats. The occasion for his pronouncement is, significantly, a survey on married women's happiness launched by Danish journalist Rosalia Jacobsen as a follow-up to her controversial article in Vita femminile italiana in defence of Italian writer Sibilla Aleramo's novel $A$ Woman. ${ }^{24}$ Sighele praises the moral battle of Aleramo's female protagonist in favour of personal freedom beyond marriage constraints at the cost of losing custody of her son, yet he does not endorse the implications of Aleramo's message for society at large. $A$

23 It should, however, also be recognized that in Eva moderna, as he attempts to embrace a more progressive stance on the feminist cause, Sighele finds it unconceivable that women who are increasingly taking on paid jobs outside their homes still need to remain under the economic tutelage of their husbands $(142,144)$, and that, ironically, no safeguarding legal measure in favour of women is contemplated whenever they are victims of male material or sexual exploitation.

24 Jacobsen's article in support of Aleramo, published in the July-Aug. 1907 issue of Vita femminile italiana, denounced women's discrimination in marriage and met the hostility of the journal's director, who warned readers not to identify with the novel's protagonist. Jacobsen then conducted a survey on married women's happiness titled "Inchiesta sulla donna e il problema dell'amore: Lettera aperta alla Direttrice della Vita femminile italiana Signora Sofia Bisi Albini," the results of which appeared in Pagine Libere: Rivista quindicinale di politica, di scienza ed arte on 1 November 1908. 
Woman may as well be one of the best novels penned by an Italian female author, but it narrates an exception that should not legitimize the many cases of female rebellion dictated by vice and immorality. Sighele does not consider adultery a crime, yet he deplores the lies at its foundation and prefers, instead, the sincerity of free love. Ironically, however, he seems to reinstate the male's exclusive property right over the female commodity, as he ultimately laments the loss of voluptuousness once all constraints and mystery dissolve in a relationship.

Although Sighele never fully overcomes his prejudices about gender differences, he sounds increasingly sympathetic to juridical problems affecting women in a rapidly evolving post-unification Italy. His public interventions on the legal unfairness that has relegated women to a condition of inferiority, like the slaves of antiquity or black people in America (Eva moderna 129), gained Sighele the reputation of a progressive thinker, as shown, for instance, by the echo of his 1906 conference at the Società di educazione della donna ("Cronaca" 63).$^{25}$ Now Sighele foregrounds the tragic consequences of the imbalance between male and female juridical responsibility. When women cannot find the strength to rebuild their lives marked by the stigma of male deceit, they react with violent, even homicidal, instincts against their partners or their illegitimate children, the innocent but blatant evidence of their shame.

These alarming social ills prompt Sighele to advocate for voting and legal rights for women, which at the time were entering a heated international debate. While New Zealand was the first country to recognize unlimited female suffrage in 1893, followed by Finland in 1906, Italy would have to wait until the advent of the Republic in 1946, but ferments in favour of female suffrage were already widespread at the beginning of the twentieth century. For instance, in 1907 the trade unionist and social activist Adelaide Coari proposes a "Programma minimo femminista" [Minimial Feminist Program] requesting women's right to vote in local elections, which in the 1920s Benito Mussolini ended up granting temporarily until a reform reassigned that right to the government. ${ }^{26}$ As for political voting, the patriot and journalist Salvatore Morelli (1824-1880)

\footnotetext{
25 Teresa Labriola herself, commenting on Sighele's lecture on feminism in front of Queen Margherita, found his sincere defence of women's rights all the more surprising, given his anti-feminist past ("Cronaca" 49).

26 See Annamaria Isastia, "La battaglia per il voto nell'Italia liberale," 31-51.
} 
had already proposed a bill in favour of equal juridical rights between men and women back in $1867 .{ }^{27}$ For his part, Sighele underscores serious inconsistencies in the Italian legal system. Although both sexes came of age at twenty-one, de facto it was as though women were recognized to be mentally inferior, given their inadequacy to exercise voting rights, while paradoxically a man of the lowest intelligence had no impediment. Beyond the juridical steps necessary to reach the milestone of universal suffrage, however, the major obstacle that Sighele highlights is women's own indifference to the problem, the result, above all, of the illiteracy of more than half the Italian female population. Sighele may have not yet digested the prospect of college-educated women he had earlier dismantled in La donna nova, but he is now at least ready to put aside his perplexities about schooling opportunities for women.

Indeed, Sighele denounces Italy's shameful backwardness with respect to other European nations, where the duration of mandatory education was at least twice as long. ${ }^{28}$ As he blames the absolutely inadequate three years' elementary schooling introduced at the time of Italy's unification, Sighele demythifies the Risorgimento nation-building enterprise. The greatness of the motherland-he polemically asserts-does not derive from patriotic military heroism but rather from a strong culture, which in his view is not even adequately served by the 1904 extension of mandatory education until age twelve. ${ }^{29}$ The need to change the Italian mentality about schooling also implies integration of women as agents and beneficiaries of education. Since this has to happen outside the family, Sighele supports co-educational classes as a more accurate reflection of actual social dynamics: This authentic and fuller life experience enabled by better culture and consequently by enhanced working opportunities is precisely what can help women gain more independence and

27 See http:/ / www.salvatoremorelli.org/parlamentoitaliano.html (last accessed 22 Jan. 2017). Although unsuccessful on that occasion, Morelli continued to introduce legislation in favour of women's rights.

28 For instance, with the 1880 Elementary Education Act, England required mandatory school attendance from 5 to 10 years of age. In France, the "loi Ferry" of 28 March 1882 mandated primary education for both sexes from age 6 to 13 .

29 Amid intense discussions about the status of Italian schools, it was the "legge Orlando," from the name of Italian jurist and politician Vittorio Emanuele Orlando, at the time minister of education, that in 1904 extended mandatory education to the age of 12. This law also guaranteed equal salary compensation to teachers across class levels, school location, and gender. 
respect, beyond their confinement to the domestic sphere and their simple sexual function.

Yet, Sighele's apparently progressive argumentation also reveals the enduring legacy of the mater salvifica ideology that had informed the rhetoric of national identity during the Risorgimento, ascribing to women a moral and political mission through their roles as mothers and educators (Romani 394). Sighele, indeed, hopes that, just as the heroes and martyrs who fought for a united Italy were animated by a patriotic faith "that their mothers' lips had instilled in them" (Eva moderna 123), the new generation, too, will rely on the maternal figure's guidance to promote harmony. These observations seem to resurrect, almost verbatim, Giuseppe Mazzini's idealization of woman as a source of moral and intellectual inspiration at once for the family and for the homeland. For instance, in The Duties of Man Mazzini extolled the mother as the initiator of the future precisely for her pivotal educational responsibilities towards her child as a budding virtuous citizen. ${ }^{30}$ This idea was further elaborated by female pedagogues in the nineteenth century like Giuliana Molino Colombini, Erminia Fua Fusinato, or Caterina Franceschi Ferrucci, who championed the education of women not only for the sake of their independence, but also for their central role in the renewal of their nation. Neither aim, however, was supposed to compromise woman's main mission as angel of the hearth, in charge of the happiness of her family's male components thanks to her moral qualities. Although Sighele agrees that the starting point of feminism is emotional and mental equality between men and women, in fact, he explicitly preserves a hierarchical difference between the two sexes. He intends to rescue the woman from rigid patriarchal impositions, but he cannot accept her brutal competition with man. Woman's aspiration to dignity and freedom of choice in relationships should leave unscathed "all her female attractiveness" (Eva moderna 155), and, like his predecessors, Sighele ascribes to society the "duty to shape the girl as a future spouse and mother" (181).

Precisely with an eye to the family, Sighele delves into another challenge inherited by the new century, namely, the social problems of childhood in Italy. The abandonment of infants, child abuse in the family, and juvenile delinquency are sensitive topics that he had already tackled

30 "From the Mother's kiss, Man learns the lesson of hope and faith in life; and hope and faith create that yearning after progress, and that power to achieve it step by step, that future, in short, whose living symbol is the infant, our link with the generations to come" (Duties 97). The mother is "for each of us the Initiatrix of the Future" (97). 
in his 1899 volume Mentre il secolo muore [As the Century Dies] and that will continue to engage him, as also shown in La crisi dell'infanzia e la delinquenza dei minorenni [The Crisis of Childhood and the Delinquency of Minors] (1911). For its magnitude, the question of abandoned infants was paramount throughout the Italian peninsula. Its main causes were not only the poverty of the biological parents or prostitution, but also the strict moral codes that would condemn procreation outside of marriage and label as dishonourable a woman's decision to raise her illegitimate child, independently of her social class. Furthermore, even when foundlings were adopted, especially by peasant families, the main underlying motif was often far from humanitarian: they were considered a good investment as future workers in agriculture. Those who remained in orphanages avoided exploitation but had to live in appalling sanitary conditions, correlated to high mortality rates (Gorni and Pellegrini 5-8). Very attentive to these ordeals and to solutions implemented by other nations, Sighele repeatedly advocates for an increase in public assistance to pregnant women-following similar measures in Paris-to help them keep and raise their children. In Eva moderna, Sighele denounces the negative effect of modernity-urbanization and industrialization, in particular-upon parent-child relationships, urging a re-examination of criteria for bringing up children in bourgeois and working-class families, broken apart by both male and female employment outside the home.

Sighele believes that it is necessary to transcend the opposition between two stereotypical extremes in the care of children, namely, the idealization of children's innocence and perfection and the demonization of children's selfishness and unruliness. Reiterating that nothing is absolute in psychology, and that "the human organism is a complicated, delicate, mysterious machine" (Modern Eve 326), Sighele opposes the projection of logical reasons on the inconsistencies of child behaviour and recommends, instead, to address the causes of those contradictions. Admittedly, his own inquiry into the child's mind still adopts the most pervasive analogy in post-Darwinian social sciences, namely-in line with the atavism he supports in his theorization of the crowd-, that between the psychology of the child and that of the primitive, impulsive savage, a surpassed stage in the mature individual's development yet retrievable at least as a trace precisely through the study of infantile behaviour. ${ }^{31}$ Nevertheless, beyond the undeniable limits of these

31 Sighele had already expressed this idea in "I bambini selvaggi," in Mentre il secolo muore $180-81$. 
unproblematic assumptions, Sighele also makes intriguing observations about children's spontaneous creativity that are in syntony with the ideas of pioneering European child psychologists. For instance, Sighele decriminalizes children's lies, explaining them as the construction of an illusory reality through autosuggestion. His referents in his exploration of the infantile creative mind are English associationist psychologist James Sully (1842-1923), author of works like Studies of Childhood (1895) and Children's Ways (1897); Swedish feminist and suffragist Ellen Key (18491925), supporter of a child-centred approach to upbringing and education; and French psychologist Théodule-Armand Ribot (1839-1916) who, in his ground-breaking Essai sur l'imagination créative (1900), which appeared in English translation in 1906 as Essay on the Creative Imagination, explained creativity as being the result of three psychological factors: the individual's emotions, intellect, and unconsciousness. Furthermore, Sighele even seems to intuit the premises of what Freud would introduce as primary narcissism when he associates childhood and imagination with the "age of the dream" (Eva Moderna 265), but he also highlights the child's cruel selfishness and the often boundless projection of the child's personality over its object of desire.

Overall, Sighele calls for a more empathetic relationship with children, based on love and identification with their imaginary world, in contrast with the accelerated maturation imposed by the abstract rules and the dehumanizing rhythms of contemporary civilization. He thus contributes to an intense ongoing debate that, since the Italian unification, had foregrounded the importance of education, physical health, and hygiene for an adequate psychological and moral development of youth. This holistic project of "making Italians" by shaping the new generation involved building values with the aid of the following: literature, well exemplified by novels like Carlo Collodi's Le avventure di Pinocchio [The Adventures of Pinocchio], Edmondo De Amicis's Cuore [Heart], and Paolo Mantegazza's Testa [Head]; proper care of the body, through a variety of approaches to physical exercise, by Emilio Baumann, Angelo Mosso, Ferdinando Abbondati, and Alberto Gamba; ${ }^{32}$ and proper care of the mind through education, as with the ground-breaking educational methods and logistical arrangements (the "Case dei bambini") pioneered

32 An interesting English synthesis of an 1893 report by the Italian Commission on Physical Education, edited by A.F. Chamberlain, appeared that same year in the Journal of Genetic Psychology.

33 For a discussion of these issues in post-Risorgimento Italian society, see StewartSteinberg, The Pinocchio Effect. 
by Maria Montessori (1870-1952). ${ }^{33}$ For his part, Sighele makes families (especially mothers) aware of the physiological causes behind their children's indiscipline before reacting with excessive severity or indulgence. From foreign cultures, especially the Anglo-Saxon, Italian society for Sighele could learn how to promote children's free expression rather than imposing uniform roles and predetermined notions. The major problem that Sighele identifies in Italian education is the strength of traditions and prejudices, which makes it difficult to apply new theories. Although his views may not sound particularly progressive to us todayand in some cases quite reactionary, as we have seen-, they were, in fact, much more advanced than the pedagogical projects circulating in the positivist circle from which he had emerged. An eloquent example is Costantino Melzi's Antropologia pedagogica (1899), which applied Sergi's anthropometric method to measure students' intellectual, moral, and physical growth using technical instruments.

Nevertheless, although Sighele transcends rigid, dogmatic positivism in the sociological and psychological domains, he remains faithful to its methodology in a particular area of inquiry, namely, literary criticism. Starting from the premise that "the artist can and must be an object of scientific analysis" (Tragic Literature 332), Sighele examines the works of leading European writers through the lens of his theories of collective behaviour, focusing on characters and situations that substantiate criminal anthropology and, in particular, his interpretation of associative crime.

\section{The Crowd in the Literature Laboratory}

Art and science are two grandiose rivers, which, despite having different courses, come from an identical source and flow towards a single-invisible and perhaps unattainable-estuary.

—Tragic Literature 333

The urgent social questions that Sighele tackles in his writings involve not only the real world, but also the literary domain. With an approach already adopted by the criminological school of Lombroso, and by positivist psychiatry in general, ${ }^{34}$ many of Sighele's critical works, now mostly

34 See, e.g., Lombroso, "Il delinquente e il pazzo nel dramma e nel romanzo," and Enrico Ferri, I delinquenti nell'arte. 
neglected, offer insightful sociological analyses of European masterpieces that reveal his gifts as a perceptive literary and cultural critic with an international vision. In works like Letteratura tragica (1906) [Tragic Literature, this volume], Nell'arte e nella scienza (1911) [In Art and in Science, this volume], and the posthumous Letteratura e sociologia [Literature and Sociology] (1914), the central questions of Sighele's scientific investigations, namely, the crowd, criminality, and the condition of women, reappear as literary topoi crafted by nineteenth-century European authors, as there is no "better document of truth than an artist's intuitions, which anticipate the theories in which we believe" (Nell'arte vii). Convinced that "the external environment influences our moral and intellectual sphere, just as it does with our body" (Sociologia 11), Sighele defends the "right to analyse works of art sociologically" (Letteratura tragica 7) because art for him has a social function.

Sighele synthesizes the main premises of what is still recognized as sociological criticism, which aims at understanding literature by placing it in a wider social context and by analysing the literary strategies adopted to depict social constructs. To be sure, if for Sighele art is "an iridescent reflection of life" (Letteratura tragica 148), he remains the child of his time for his often narrow treatment of the literary work as a natural phenomenon worthy of scientific attention, and as a confirmation of predetermined scientific hypotheses. At times, however, Sighele problematizes the relationship between aesthetics and science or the underlying social forces, and even seems to deploy the distinction that, already with Friedrich Engels (1820-1895), transcended the static Marxian dichotomy between economic structure and aesthetic superstructure. Just as for Engels ("Against" 39) art not only reflects but also influences real life and the course of its historical struggles, Sighele's argumentations often underscore the active role that literature and culture can play to modify the social context. ${ }^{35}$

On the one hand, in Letteratura tragica Sighele defines the literature of his time as "a clinic" (150) because of its almost exclusive focus on mephitic emotional contexts and degrading urban environments in which

35 We notice this two-directional dynamics at work also in Sighele's discussion of public opinion, where journalists and their audience are described as influencing each other: "every public produces journalists who have its instincts, its tendencies, its talents, and its flaws; [...] but once the public has, so to speak, given birth to its journalist, he, like the son towards his parents, will start to influence the public, to guide and modify its opinions" (Intelligence 253). 
individuals are victims rather than protagonists. On the other hand, he also dissociates himself from what he portrays as notorious enemies of art like Max Nordau (1849-1923) or Cesare Lombroso. He intends to show that aesthetic activity can be analysed according to scientific parameters without affecting its beauty, even when, as in the case of modern literature, its objects of study are the abnormal and degenerate aspects of life, the "ugly, morbid, or evil" (Tragic Literature 333) instances of reality rather than the idealized realm of the good and the beautiful. Given his interests in the anthropological, psychological, and contextual causes of deviant human behaviour, Sighele's main field of investigation is therefore what, since the theories of Émile Zola (1840-1902), has come to be known as the experimental novel, engaged in a dialectical relationship with science, aiming at an objective reproduction of the real according to the laws of nature, and morally committed to act on social phenomena. Sighele endorses what for him are socialist and naturalist writers, as well as their forerunners, who compassionately expose moral illnesses not to punish vice, but rather to heal society. Among these brave allies of science, for him equipped with powerful intuitions and a documented knowledge of psychopathology, we hence find Émile Zola, Eugène Sue, Honoré de Balzac, and also the writer whom Sighele considers the Italian genius, namely, Gabriele D'Annunzio.

The portrait that Sighele provides of this kaleidoscopic figure, who ferries Italian literature from naturalism to symbolism and aestheticism and, ultimately, to modernism, may sound particularly intriguing to readers of our time, generally much more attuned to the Dannunzian apostle of beauty, the exceptional individual divorced from social problems and collective manifestations. For Sighele, life in D'Annunzio consists of a duel between the individual and his two fatal enemies-woman and the crowd-which propel progress and bring together aesthetic, anthropological, and political concerns. In the second edition of L'intelligenza della folla (1911), Sighele is captivated by D'Annunzio's ability to grasp the tumultuous emotional contradictions of the individual confronted with the multitude as much as with woman. ${ }^{36}$ Both trigger male desire to possess and conquer. Sighele highlights the centrality of collective psychology in D'Annunzio's works, from the superhuman contempt for

36 Arguably Sighele shares with D'Annunzio the "inconfessato amore e [...] desiderio inconscio" (Intelligenza 57) [unavowed love and [...] unconscious desire] that even the most self-centred of authors is said to conceal behind his alleged hatred for the multitude and for woman alike. 
the revolting mob in Le vergini delle rocce [The Virgins of the Rocks] (1895) and La Nave [The Ship] (1908) - the symbol of an overwhelming democracy - to the fecund communion between the artist and an inspiring multitude that reinvigorates individual creativity thanks to its mysterious choral force. ${ }^{37}$ Already in Tragic Literature, indeed, D'Annunzio's works are said to blend realistic types with characters and situations deriving from an "unlikely and unnatural" (336) imagination. Although Sighele does not appreciate the more symbolistic developments of D'Annunzio's writings, he endorses these marked contrasts as evidence of the aesthetic novelty of his time, namely, the ability of art and even its authority to engage in a dialogue with science.

Thus, besides representing the scientifically perfect "moral neurasthenic" (Tragic Literature 337), D’Annunzio's eponymous protagonist of Giovanni Episcopo also engages in a conflictual relationship with his rival Giulio Wanzer that epitomizes the dynamics of Sighele's degenerate couple. The succubus ends up savagely revolting against the suggestion of the incubus, ultimately killing him. For their part, the remorseless premeditation and the egoism that lead Tullio Hermil to infanticide in Linnocente [The Intruder] pertain to the typology of the born criminal, refined rather than brutal, but genetically devoid of moral sense and able to conceal his perversity under his elegance and ingenuity. With no less psychiatric accuracy despite its implausibility, the oneiric tragic poem Sogno di un mattino di primavera [Dream of a Spring Morning] (1914), a one-act play, for Sighele convincingly documents Isabella's downfall from extreme happiness to the paralysis of intellectual faculties at the sight of her lover's murder, and the lucidity with which she relives the most heart-rending moments-an almost photographic "artistic resurrection" (Tragic Literature 342) of events that occur in mental asylums.

Once D'Annunzio ceases to be faithful to real phenomena validated by experimental observation, his characterization for Sighele succumbs to exaggeration, beyond positive truth. Yet, Sighele does not give up categorizing Dannunzian characters according to anthropological parameters. Giorgio Aurispa, in D'Annunzio's Trionfo della morte [The Triumph of Death] (1894), can thus represent the abortive madness of the "superior degenerate" (Tragic Literature 343) who self-inflicts psychological

37 To D'Annunzio's La Nave, Sighele also devotes a chapter in Nell'arte e nella scienza [In Art and in Science], where he praises the author's ability to draw "all the turmoil of collective life with the precision of a physiologist who plots on paper, in the oscillating lines of a diagram, the emotions of the human heart" (Nell'arte 178). 
torture through an unforgiving self-analysis, while on the entirety of The Virgins of the Rocks-for Sighele the most incomprehensible and emptiest of D'Annunzio's novels-there looms the nightmare of a collective hereditary insanity that overturns the author's intent to highlight the vitality of an aristocratic race..$^{38}$ Predictably, therefore, Sighele cannot a fortiori come to terms with the "abnormal idea" (Tragic Literature 345) of Nietzschean superhumanism. He censures it as an acritically imported foreign theory that, in properly Sighelian terms, exerts its power of suggestion upon D'Annunzio and, as an alleged illness affecting his characters, ends up infecting him as well from the psychological, aesthetic, and moral point of view.

Without overcoming his taxonomic bias, at the apex of D'Annunzio's art Sighele finds exceptional individuals or pathological moods, rather than physiological and psychological normality. While he disapproves of D'Annunzio's aesthetic turn, Sighele underscores the precision with which the author reconstructs and analyses environment, objects, behaviours, and moral parameters by dissecting scenes, dialogues, and impulses even in his least verisimilar works like Francesca da Rimini or La Figlia di Iorio [The Daughter of Jorio] (1904). Likewise, in La fiaccola sotto il moggio [The Torch under the Bushel] (1905)—for Sighele the least convincing because of its technical and at times melodramatic excesses-Sighele lingers on strong passions like hate or jealousy, and crimes like uxoricide, examining characters as defendants in a trial. Sighele thus proves more engaged and open-minded than a more recent sociological critic like Georg Lukács, who condemns modernist literature in bulk precisely for the "abstract particularity" ("The Ideology of Modernism" 1230) of its eccentric, singular protagonists-alienated personalities whose psychopathology distorts rather than portrays the typicality of realism, with its dialectical unity of character and environment. Sighele maintains that at the outset of the century "we are all more or less deranged or neurotic" (Letteratura tragica 149), hence implying that what Lukács would later decry as "the disintegration of personality" ("Ideology" 1229) and the subjective world-view it entails are the rule instead of exceptions.

Undeniably, however, Sighele's sympathies go to depictions of humble and even morbid characters that still place social and moral conditions at the centre of representation as forms of what Lukács endorses as

38 Sighele adopts a similar approach in his chapter "I tipi femminili nell'opera di Gabriele D'Annunzio" (Nell'arte 105-62) on D'Annunzio's female characters, which are made to comply, even more rigidly than their male counterparts, with behavioural and moral typologies. 
"concrete criticism" ("Ideology" 1224) rather than "rejection of reality" (1224).For diametricallyopposite reasons to his evaluation of D'Annunzio, it is in Eugène Sue (1804-1857) that Sighele locates a precursor of the positivist approach. Although he finds the French novelist quite insignificant from the point of view of form, Sighele foregrounds the scientific value of his ideas which, as exemplified by his masterpiece The Mysteries of Paris, foreshadow pivotal issues in criminal anthropology-the analogy between the barbarian "other" and the criminals of his time, the arrested development that confines the criminal to a state of savage brutality, and the connection between physiognomy and temperament in the typologies of degeneracy that Sue sketches "with Lombrosian precision” (Letteratura tragica 100). Sue's novels, therefore, are for Sighele a "copious reserve of documents" (115) that, inspired by real life, study phenomena like prostitution, sexual crimes, violent murders, and civil injustices with an approach that foreruns modern sociology. Furthermore, Sighele praises the brilliant intuitions with which Sue transcends rigid categories (like that of the born criminal) and, rather, underscores the complexity of moral attitudes, hence also the contradictions of criminal psychology. The examples of suggestion he draws from Sue help Sighele validate the main point of his theory, namely, the treatment of collective psychology as the psychology of the unexpected that suddenly modifies the individual's moral choices for good or bad. Sighele endorses, for instance, Sue's hostility to penitentiaries as dangerous spaces of suggestion, and his promotion of alternative social establishments, like provident institutions and agricultural colonies to aid the poor or rehabilitate former convicts. The displacement of Sue's character Chourineur from the deleterious Parisian environment to an African farm, represents for Sighele a successful redirection of violent instincts towards socially useful activities, showing Sue's enduring involvement in the prevention of evil and the promotion of the common good through an art of hope rather than of fear.

In this way, Sighele distances himself from mere literary depictions, dissections, and diagnoses, which for him typify a superficial naturalism and, rather, urges the novel to move from social pathology to therapy. French literature offers Sighele other exemplary models of criminal and spoiled settings drawn from the world of true suffering by authors committed to the social function of literature. Émile Zola's works lucidly present the indissoluble link between heredity and environment without drifting into psychological absolutism or falling back into simplistic atavism. Zola's representation of the "fearsome unknown of the collective soul" (Letteratura tragica 158) so crucial to Sighele does not produce 
"infinite copies of a single type" (156), but, rather, connotes each character and action taken individually, like multiple rays emanating from the iridescent prism of life. Zola's detailed analysis of the remorse that stops the homicidal instinct in Jacques Lantier or the crime of the mob of miners degraded by work and inflamed by the redemptive communist promises even beyond their meneurs'intentions in Germinal demonstrate for Sighele that Zola's art can divulge scientific truth not only by highlighting its two conquests-namely, the discovery of the anthropological type of the criminal and the creation of collective psychology-but also by humanely judging the obscure depths of the multitude's soul and the material causes that awaken it, calling for remedies.

On these principles, in In Art and in Science Sighele intends to revive the work of Honoré de Balzac (1799-1850), surprisingly overlooked by both Lombroso and Ferri in their anthropological and psychological studies of literary texts. Sighele himself admits having neglected, until then, the colossal Human Comedy, which he defines as the most extensive and complete representation of life produced by a writer who "carried an entire society in his brain" (Art 377). Balzac's genius-Sighele insightfully claims-lies in its ability to condense at once the spirit and morals of his time and the psychological truths of ours, expressing both of them through his characters' actions and personalities instead of preaching in the first person. It is hard to believe that certain statements "with a flavour of liberalism and socialism" (Art 403) in the Human Comedy do not come from an extreme left-wing deputy but, rather, from "a conservative and reactionary author who did not hide his sympathy for the Bourbons" (Art 403). In these poignant observations we hear echoes of Engels's praise of Balzac as a great master of realism for his depiction of emerging popular masses "against his own class sympathies and political prejudices" ("Realism" 40) in favour of a nobility doomed to extinction.

Among the numerous issues that Balzac tackles in his novels, Sighele predictably lingers on those that are in syntony with his field of investigation-at times magnifying his own idiosyncracies. Thus, in the claims of the Count of La Palferine on women and love, for instance, Sighele finds truths that substantiate his own theory of female psychology revolving around the excesses, volubility, and attachments of the female heart. Likewise, Sighele praises the acumen with which Balzac grasps the peculiar behaviour of criminals, who are always ready to declare their innocence. Sighele, for his part, confirms this regularity by foregrounding the exception represented by the "aristocracy of crime," that is, the tendency of the most fearsome and perfidious criminals to boast of their offences. For his ability to differentiate the psychology of great 
criminals from that of common delinquents Balzac therefore deserves a place in a genealogy of jurists, physicians, and anthropologists-from Prosper Despine (1812-1892) and Gabriel Tarde to Cesare Lombroso and Enrico Ferri-who have substantiated his hypothesis. Furthermore, Sighele finds in Balzac a poignant precursor of his own inquiries into the deleterious effects of detention upon the convict's psyche. In open polemics with the legislators of his time, Sighele, indeed, reiterates his denunciation of the economic and social inefficiency of the prison system, further elaborating on his claims on Eugène Sue.

The climax in Balzac's characterization of the prison environment is, predictably, Vautrin, for Sighele a masterpiece not only of psychological accuracy, but also of aesthetic creation. Much more effectively than through physiognomy, Balzac provides the moral portrait of a "poet of evil" (Art 399) who, thanks to remarkable intuition and absolute unscrupulousness, can manipulate people to his advantage. Vautrin's undeniable attractiveness even leads Sighele to endorse a notion that he had earlier deplored in his analysis of D'Annunzio, namely, that of the "superman against the crowd" (400), which here connotes an exceptional "truthful soul" (401) able to abstract from the particular to the universal. Vautrin is an "unconscious ironist" (402) who can denounce with philosophical cynicism the selfishness and wickedness that are ingrained within the majority, yet hypocritically silenced. Vautrin is equally pivotal to substantiate the typical dynamics of Sighele's criminal couple, since, as Vautrin himself declares, he needs an accomplice, a creature he can model at his own will. His future succubus is Lucien de Rubempré, caught in the magnetic bond of the suggestion à deux that for Sighele synthesizes more extended human associations, and ultimately driven to suicide. Even the fact that Vautrin escapes incrimination despite his ruthlessness belongs for Sighele to the logic of verisimilitude rather than of implausibility, since real life presents no less unbelievable legal cases, like that of the criminal and criminalist Eugène François Vidocq (1775-1857). With his strength and charisma, Vautrin clearly validates the law of inequality that Balzac masterfully captures through the inverse relationship between genius and morality. Hence, Vautrin ultimately takes revenge against a cowardly and impotent society that has failed to punish him.

These provocative statements on the inefficiency of laws and magistrates transcend the literary realm. In this interpretation of Balzac's message we can also hear Sighele's polemical stance towards legal and political measures in the society of his time. Like Sighele, indeed, Balzac the great expert of collective psychology fully perceives the gap 
between individual and political morality, and expresses reservations about the role of parliament, given the unpredictability of the crowd and the risks entailed by its own sovereignty. The author of the Human Comedy becomes Sighele's soulmate, as Sighele himself had earlier attacked the parliamentary system, stirring strong reactions in the political and social sphere.

\section{Collective Bodies, Collective Souls: Sighele, Politics, and Their Aftermath}

We need to campaign here, among the populace [...] if we really want to save the Italianness of the country, and, with it, its ideal.

—Sighele's unpublished letter to Giovanni Pedrotti, 30 Aug. 1908

For Sighele 1895 is quite an upsetting year. It shadows his international scientific recognition with the publication of Le Bon's book, and also provides ample evidence of Italy's political dysfunctionality. The transfer of power from the king to the government, which, for decades already, had given more autonomy to the parliament, had led to continued violations of the basic rules of the system. In particular, the closing of parliament had become a dangerous habit that prevented confrontations between the government and its opposition, often entailing the dissolution of the two chambers. All pending bills would decay and the government could no longer perform its functions. Prime Minister Crispi frequently exploited this strategy between January 1894 and June 1895, but he was certainly not the only one. ${ }^{39}$ These parliamentary abuses prompt Sighele to publish the pamphlet Against Parliamentarism: An Essay on Collective Psychology, ${ }^{40}$ where he denounces not only the flaws of the current Italian political system but, more generally, the inefficiency of the parliamentary form itself.

Sighele is certainly not alone in condemning the government, hence dealing yet another blow to the ideal of a respected unified Italy. Many other intellectuals and writers criticized Italian politics in the same

39 See Merlini, "Il governo costituzionale," 19-20.

40 Later republished in Sectarian Criminality. 
period, from Matilde Serao (1856-1927) with her depiction of the inefficiency and hypocrisy of the government in Il ventre di Napoli [The Belly of Naples] (1884) and of Italian politicians' careerism in her parliamentary novel La conquista di Roma [The Conquest of Rome] (1885), to Paolo Mantegazza (1831-1910) with his ironic recollections of his experience as a senator in Ricordi politici di un fantaccino del parlamento italiano [Political Memoirs of a Foot-soldier in the Italian Parliament] (1896), and V.G. Sanfelice's critique of the deputies' ignorance in La coltura degli uomini politici [The Culture of Politicians] (1897). Sighele, however, does not only intend to denounce the selfishness and immorality of individual politicians or political parties. He is more in line with the "Italian School of Elitists," including political scientists Gaetano Mosca (1858-1941) and Vilfredo Pareto (1848-1923), who challenged the parliament as an intrinsically flawed institution, doomed to further degeneration along with the extension of suffrage and the consolidation of mass political parties. In his 1883 Sulla teorica dei governi e sul governo parlamentare [On the Theory of Governments and on Parliamentary Government], Mosca denounces the group interests behind the parliamentary systems and upholds greater power to the king and to an educated, independent political minority. Similarly, Pareto associates the failure of the parliamentary system with the lack of actual differentiation among Italian political parties and of private initiative, highlighting, instead, widespread connivance for specific personal interests. His critique contains the premises of his subsequent vision of history as an alternation of aristocracies opposed to masses in The Rise and Fall of the Elites (1901).

For his part, with even stronger undemocratic implications, Sighele highlights the inadequacy of the parliament as a collective organism, doubting that many people can decide better than one. The psychic elements of individuals gathered in an assembly generate for him "an unknown quid" (Sectarian 198) that annuls single intelligences and the intellectual value of the decision at stake, hence determining an inevitable mediocrity. Although he does not avow a preference for the authoritarianism of the single individual, Sighele sees parliament as the locus of a potential tyranny of the many, of numbers, of the mass. In line with his psychological theory on collective behaviour, the majority's right in politics seems to Sighele not only illogical, but also dangerous because the volatile emotions and opinions of the assembly members may erratically overturn decisions at any time, with uncontrollable consequences. The sudden randomness in the functioning of parliament does not only pertain to the deputies' deliberations, according to Sighele, but also to 
their election. For him, to vote is not a free action but, rather, the result of a hypnotic force that, through speeches and newspapers, influences and manipulates the audience (Settaria 254). Electoral behaviour hence exemplifies the functioning of public opinion that he describes in The Intelligence of the Crowd, even if he considers the judgment of a scattered audience more reliable, because impressions and reactions are more intense when they are in unison. The power of suggestion affects with equal strength parliament's morality, which for Sighele is tainted by social corruption, voting frauds, and hypocritical libelling and praises.

Sighele is so carried away by this alleged example of sectarian criminality that he indulges in quite daring similes aimed at reinforcing the connotation of parliament as an unmanageable, degenerate collectivity. The Chamber of Deputies is not only psychologically female and hysterical-as we have seen-but also like a group of children whose propensity to evil increases when they form a group. Both images support Sighele's deterministic conviction that no remedy exists to the ills of that intrinsically flawed political institution, yet he indicates ways to limit its damage to the nation: either to reduce the number of parliamentarians or to promote regional autonomy so as to let the corrupted fixers stew in their own juice in Rome-, an intriguing idea for our own times, considering the current debates about the so-called devolution in Italian politics and the separatist regionalism of the Northern League, but certainly contrary to the unifying impulse that had recently made Italian nationhood a reality.

Not surprisingly, Against Parliamentarism raised a remarkable controversy that also tarnished Sighele's scientific reliability. Italian socialist politician Leonida Bissolati (1857-1920) attacked Sighele's premises and the almost non-existent scientific seriousness of his applications ("Pseudopositivismo" 88), maintaining that parliament was not born in reaction to hereditary and individual tyrannies but, rather, as a result of human spontaneous gregariousness, and by the action of the bourgeoisie. For his part, Italian deputy Francesco Ambrosoli (1854-1908) responds with Salviamo il Parlamento! [Let's Save the Parliament!], where he criticizes Sighele's unilateral view and his simplistic explanation of the parliament's procedures: Sighele should have at least limited his condemnation to Latin regions instead of generalizing to include even the prototypical, fully functioning English model (Salviamo 6-7). Furthermore, Sighele equates the parliament to the Chamber of Deputies without mentioning the Senate. Overall, Ambrosoli urges Sighele to look beyond the problems of the specific Italian government that probably triggered 
his attack, and to consider edifying examples of great deliberations offered by political institutions at large across time. ${ }^{41}$ Ettore Lombardo Pellegrino (1866-1952), too, deplores Sighele's axiomatic approach to deputies' irrational behaviour which for him is, in fact, neither extendable to parliament in general nor, a fortiori, tantamount to human nature, but, rather, only an altered and modifiable state (Parlamentarismo 64). Even the more sympathetic Pietro Chimienti (1864-1938), who defended Sighele's intelligent and original application of collective psychology to criminal crowds, is puzzled by Sighele's pessimistic drift and by the death sentence he inflicts to parliamentary institutions. He objects to Sighele that collective psychology cannot be reduced to crowd behaviour. While the crowd acts upon few and simple emotional elements, a complex political assembly has intellectual, critical, and moral faculties. Life cannot be understood from such a narrow perspective (Vita politica 319).

Antiparliamentarism is not the only controversial aspect of Sighele's intellectual trajectory. The other burning issue is his notoriety as a nationalist, mainly deriving from his irredentism and at times approached unilaterally by critics without enough contextual evidence. Sighele's attachment to his unredeemed Trentino region, which had been under the Austrian regime since the Third War of Independence (1866) despite its Italian indigenous population, prompts him not only to adhere to local Italian cultural institutions like the Società Dante Alighieri, but also to contribute to the creation of an Italian university in Innsbruck in 1903 and to envisage a similar initiative in Trieste. Both projects aborted, because of the strong opposition by local Austrian authorities and students, as Sighele recollects in his Pagine nazionaliste [Nationalistic Pages] (1910). Sighele regularly hosted sympathizers of the irredentist cause in his villa at Nago, on the coast of Lake Garda in the province of Trento. After several trials for his subversive activity, in the summer of 1913 an order from the Austrian commissioner gave Sighele eight days to leave

41 The magnitude of the echo created by Sighele's pamphlet is such that Ambrosoli's intervention stirs, in its turn, the reaction of Filippo Turati who, while not strenuously defending Sighele, attacks Ambrosoli's bourgeois ideology. See Turati, "Micrologia politica," Critica Sociale (16 March and 1 April 1895). Other critics of Sighele's antiparliamentarism include E. Pinchia, La bancarotta del Parlamento? (Roux, 1895); Leonida Bissolati, "Pseudopositivismo," in Critica Sociale (1 May 1895); and V. Miceli, "Come salvare il Parlamento," in Riforma Sociale (10 Sept. 1895). 
the region. ${ }^{42}$ This was the final blow to his already precarious health. Scipio Sighele died in Florence a few months later, on 21 October 1913.

To resurrect the hopes of his unredeemed land is, not accidentally, the main impulse animating Pagine nazionaliste, Sighele combined Risorgimento patriotism with a liberal form of irredentism that grew particularly fervent after Austria's annexation of Bosnia Herzegovina in 1908. In order to gain Italy's consensus and support for the cause of Trento and Trieste, Sighele joined the Associazione Nazionalista Italiana, led by the reactionary writer and politician Enrico Corradini (1865-1931), and participated in its 1910 congress in Florence despite his dissent with Corradini himself. On that occasion, Sighele expressed the main theoretical ideas that would then converge in his volume, namely, his hostility to impulsive imperialism and the pivotal role of culture and institutions in the defence of Italian nationality in the unredeemed areas of the country. The growth, however, of antidemocratic right-wing tendencies in the association induced Sighele to abandon it, ${ }^{43}$ and to keep alive his political commitment through writing. In Pagine nazionaliste, addressing new generations in particular, Sighele aspires to promote consciousness of and pride in the nation. Writing from Nago, he foregrounds his condition

42 The echo of Sighele's expulsion was remarkable, as demonstrated by the numerous Italian newspaper articles on the episode, as well as telegrams and letters of support sent to Sighele and collected by his wife, currently archived at the Fondo Sighele. Some of those texts emphasize that, since Sighele is a naturalized Italian citizen, by expelling such a high-profile and much respected intellectual, Austria deliberately attacked the Italian people as a whole, demonstrating all its hatred against them.

43 Both Palano and Bosc attempt to draw a more articulated profile of Sighele, beyond unilateral examinations of his political ideals as consistently anti-democratic, nationalist, and imperialist. Palano explains Sighele's alleged antiparliamentarism not as an authoritarian stance but, rather, as an application of his own theories on political crime to a critique of Italian politicians' parasitism, in the attempt to reduce, at least, the number of parliamentarians (Potere 340-41). Bosc provides details about Sighele's relationship with Corradini, and his ultimate separation from the Association once its reactionary orientation condemned the three values that Sighele wanted to preserve, namely, democracy, socialism, and internationalism (Bosc Foule 347-48). Already Cipriano Giachetti, commemorating Sighele in La Nuova Antologia a few months after his death, had underlined how his nationalism was "a theoretical and practical sublimation of his Italianness" ("Sighele" 99) but did not coincide with a political party, hence his worries about the anti-proletarian tendencies of the Italian right. Likewise, in his biographical introduction to Sighele's posthumous collection Letteratura e sociologia, Gualtiero Castellini, Sighele's nephew, highlights the continuity in Sighele's concerns with his small and great homeland (respectively, Trentino and Italy), in the framework of a nationalism with a philosophical foundation outside political parties (Letteratura xiii). 
as a border intellectual, showing the complexity of Italy well beyond the abstract simplification of its unification, in contrast to the prevailing ignorance of politicians and citizens about geopolitical boundaries and the ordeal of territories still unfairly subject to Austria. Sighele describes the Trentino region as the slave of Tyrol, given the inadequate number of deputies to represent it, the scarcity of its economic resources, and the availability of exclusively German newspapers to its Italian population. Yet, he explains that, unlike the irredentism of the Risorgimento period, the struggle he defends and foresees for the Trentino region is not a military but a legal one, in defence of economic and administrative rights, as well as of nationality.

Sighele connects Italy's indifference towards the Trentino's struggle for liberation from Austria to a wider discussion of the political and cultural importance of internationalism. In his view, Italy neither feels nor understands foreign policy, because its citizens travel very seldom, read very little, and do not invest enough in culture, while other nations enjoy higher profiles thanks to well-respected cultural institutions. A narrow psychology keeps Italy hostage to a parochial pride in visceral petty ideals that translates into political myopia and lack of authentic patriotism. Sighele interprets nationalism in much broader terms than either mere anti-Austrian sentiment or French reactionary legitimism. Nationalism to Sighele amounts to the creation of "a collective national soul" (Pagine 235). Significantly, on the one hand, in line with the premises of his collective psychology, Sighele implies that local individualities (citizens or regions) are better than their national whole. On the other hand, however, here he re-evaluates the positive potential of collectivity as he envisages an Italian soul able to overcome the mediocrity of the present by rising above regional vanities. Between echoes of the unfulfilled Risorgimento dream and intimations of the patriotic mirage that would soon degenerate into the nightmare of Fascist dictatorship and of its colonial enterprise, a nationalist for Sighele is "a man who feels proud of his own race and Latin civilization, and wants to defend them against foreigners, who attempt to denaturalize them" (222). Sighele

For his part, in Il nazionalismo e i partiti politici, Sighele will go as far as to justify imperialism as self-defence (80-81), and war as a necessary consequence, a matter of survival for Italy. The occupation of Tripolitania appears to him almost like a moral obligation after Italy's sacrifices for the Triple Alliance (87). Yet, in her detailed reconstruction of Sighele's political thought, Maria Garbari substantiates Giachetti's and Castellini's views, interpreting Sighele's controversial stance on both nationalism and imperialism in a Risorgimental perspective ("Pensiero" 545). 
thus provocatively avows no fear of being accused of imperialism, if this term describes Italy's attempt to lead its politics beyond the humiliating stereotype of a "little boat trailing behind the grand Austro-Hungarian ship" (182) or of a powerless garden of Europe, and gain its own dignity. Halfway between cowardly resignation and defiant provocation, Sighele claims the right to one's own defence without being a medieval warmonger or silently accepting injustice.

Critics maintain that Sighele allegedly resisted the appeal of extreme right-wing politics and defended the kind of moderate, liberal, international thought that Fascism would later attack as an example of positivist democracy (Bosc, "Foule" 45). It cannot be neglected, however, that the theoretician of crowd psychology ultimately falls into the trap of collective suggestion when, less than a year after these pronouncements, Prime Minister Giolitti rekindles Italy's expansionist ambitions obtaining vast support thanks to a huge lobbying operation by the Italian press, able to turn public opinion into mass opinion, in proper Sighelian terms. The invasion of Libya inflames Sighele to such an extent that, despite his poor health, he travels to Tripoli to see the battle with his own eyes. A probable surrogate target for his unredeemed region, the prospect of an Italian Tripoli confirmed to him that his nation could successfully employ equal energy for other victorious enterprises closer to home and to his heart. ${ }^{44}$

Scipio Sighele died as a forty-five-year-old exile, six years before history began to realize his irredentist dream, but inevitably with the use of military force and at a very high price. The Trentino region was annexed to the Kingdom of Italy in 1919, at the end of the First World War, with deep social lacerations within the region, torn between Trentino soldiers fighting in the Austrian army and irredentists on the Italian side, and ultimately penalized by heavy repressions on both fronts, internment, and the massive exodus of Trentino refugees. As for Trieste, its ordeal will not end with the 1920 ratification of its liberation. More foreign occupations will follow after the Second World War. More criminal crowds, manipulated by extremist political ideas, will exert their

44 See his argument about irredentism and the war in Libya in "La nouvelle psychologie irrédentiste depuis l'expédition tripolitaine" (145). Significantly, a note of Sighele's wife on the archived copy at the Fondo Sighele specifies that a lecture he had earlier prepared to deliver in Milan on the same topic was prohibited. He hence published it abroad in article form, yet it enraged Austria nonetheless, and was probably the decisive factor that determined Sighele's expulsion from Trentino. 
violence before this last portion of Italy could move to the coveted side of that disputed border.

Crowd psychology did not have a considerable following in Italy after Sighele's death. His notable disciple, who died prematurely in 1905, is Pasquale Rossi (b.1867), who further developed Sighele's ideas on collective psychology in works like Psicologia collettiva [Collective Psychology] (1898), Psicologia collettiva morbosa [Morbid Collective Psychology] (1901), and the posthumous Sociologia e psicologia collettiva [Sociology and Collective Psychology] (1909). Rossi differentiates between sociology as the study of collective bodies and collective psychology as the study of collective souls. He modifies Sighele's theory by assuming that the crowd has a soul and rational faculties, hence it can be educated and is not necessarily prone to crime. With this twist he erases Sighele's distinction between homogeneous and heterogeneous subjects.

Sighele was mentioned quite regularly by the foreign press in his lifetime. Whereas in France his intense correspondence with Gustave Le Bon and Gabriel Tarde and the numerous translations of his works reinforced his scientific profile as a criminologist and sociologist, his reception in the anglophone world, where none of his volumes were translated, sketches a more superficial yet multifaceted portrait. In the American journal Popular Science Monthly, Helen Zimmern places turn-of-the-century Italy at the forefront of criminal anthropology and of other branches of social sciences to which Sighele contributes, in her view, as a highly cultivated and fine observer. Nonetheless, he often "jumps to conclusions too rapidly" ("Criminal Anthropology in Italy" 758), especially on "matters English and American of which he has but the most superficial and secondhand knowledge" (758). In a previous article for Blackwood's Edinburgh Magazine, Zimmern had devoted an extensive discussion to the "truly remarkable" ("An Indictment of Parliaments" 227) work of Signor Scipio Sighele on collective psychology, applied in particular to the institution of parliament. In much more favourable tones than her Italian contemporaries, Zimmern qualifies Sighele's argument as theoretical rather than militant, and adopts it to undermine England's overconfidence in its own representative government, given the intrinsic weakness of the parliamentary institution in general as an unpredictable "assemblage of many persons” (228). In August 1896, Reynold's Newspaper announces the English publication of Sighele's article "Individual Morality and Political Morality-A Sociological Problem" in the journal To-morrow, offering a synopsis of its major theoretical points. Likewise, on 10 September 1901 the London Daily News, reporting on the papers presented at the Fifth International Congress of Criminal Anthropology in Amsterdam, 
summarizes Sighele's theory of collective crimes, highlighting the relationship between succubus and incubus, the role of suggestion, and the reduction of individual responsibility in a crowd.

Yet, it is once again for political reasons that Sighele's thought stands out, often co-opted with rather tendentious aims. In a survey of international opinions on Great Britain on the occasion of the Anglo-Boer War, the Morning Post (30 Oct. 1899) praises "the eminent Professor of Sociology and Anthropology" (3) Scipio Sighele for his endorsement of Britain's attack on the assumption that "the more civilised nations have the right to absorb the less civilized" (3). Over two decades later, Micklem and Morgan's volume Christ and Caesar, which supports the idea of an intimate relationship between the individual and mankind through the mediation of the nation, assimilates Sighele's nationalism to an extreme form of "Jingoism and imperialism" (137), inspired "by a desire for power much after the manner of Nietzsche" (137). Sighele, they conclude, "is as indignant with pacific and humanitarian sentiment in the political realm as is Sorel or Lenin with any show of mildness in the industrial sphere" (137).

However, the aggressive affirmation of national sovereignty that here seems to taint the Italian intellectual's reputation appeared under a quite different light in the commemorations of his death. On 13 November 1913, the American weekly periodical the Nation remembers "one of the most distinguished Italian sociologists, [...] banished by the Austrian government for asserting his ideals of political liberty" (457). Besides sympathy for Sighele's political vicissitudes, the author of the obituary, Harvard University scholar Rudolph Altrocchi (1882-1953), extols his high patriotic ideals, including his glorious manifestation of nationalism in the Tripoli campaign. Altrocchi provides a flattering portrayal of Sighele as "both scientist and artist" (457), not only "a pioneer" (457) in collective psychology, but also a deep connoisseur of literature and a psychological critic who skilfully analysed "social evils and the character of crowds" (457) in real life as well as in fiction. Altrocchi's edifying obituary equally upholds the political repercussions of Sighele's sociological vision, rectifying that the psychological inferiority of the group with respect to the individual does not lead in Sighele to a pessimistic philosophy of government. Rather, it is propelled by a proactive "ideal philanthropy" (458) that moves from the improvement of the individual to that of social and political collectivity.

In the United States, Scipio Sighele's works initially became known mostly through their French translations, as we can see from a review article by American scholar Albert Schinz (1870-1943) in an 1897-98 issue 
of the American Journal of Psychology. Schinz introduces Psychologie des sectes, the French translation of Sighele's La delinquenza settaria, in the framework of the current reinterpretation of individual and collective crime. Schinz acknowledges Sighele's ground-breaking contribution in Italy and his claim to priority over Le Bon in the study of crowd psychology; nevertheless, he ranks Le Bon's truly scientific approach higher than Sighele's voluble and repetitive argumentation (597). Curiously, however, an anonymous piece in an earlier issue praises Sighele's "interesting and comprehensive review of collective psychology, past and future" (416), penned by a "more critical and detailed" (416) author than Le Bon. In 1901 the periodical the Humanitarian publishes an article in English by Sighele, "The Moral Problem of Collective Psychology," followed a year later, by a political piece in the International Monthly on "Latin Europe and American Imperialism." Here Sighele extends to international policy the psychological dynamics of the crowd that in Sectarian Criminality explain the relationship between lower and higher social strata: "the humbler among the nations may supersede the greater, corrupted and weakened by excess of power and by their overweening pride" (670). Sighele maintains that "[e]very nation that flourishes inevitably becomes imperialist, just as every man who succeeds in life absorbs and centralizes subordinate elements" (662), hence, from a philosophical point of view, imperialism should not be condemned a priori, but rather examined lucidly.

Between acclaim and controversies, Sighele can be said to gain canonical status in the United States in the 1920s, after a section from his Psychologie des sectes, translated into English and titled "Types of Social Groups," appears in Introduction to the Science of Sociology, edited by Robert Park and Ernest Burgess and published in 1921. Inclusion in this volume, which was conceived as "a systematic treatise" (v) rather than "a mere collection of materials" (v), consecrates Sighele as an internationally renowned scholar, and the only Italian one, among eminent figures like Émile Durkheim, John Dewey, Alfred Binet, William James, Ferdinand Tönnies, and Théodule-Armand Ribot. Indeed, as the editors write, "Tarde and Le Bon in France, Sighele in Italy, and [Edward Alsworth] Ross in the United States were the pioneers in the description and interpretation of the behavior of mobs and crowds" (213), a topic in which the editors acknowledge "an increasing interest" (213).

Yet, to be sure, the past tense "were" also underlines that, by then, those innovative theories of collective psychology had become history. As Ernesto Laclau claims, an "ideological anti-popular bias" (Populist 40) shaped those argumentations upon the rigid dichotomy of the rational, 
normal individual and the irrational, pathological crowd. More flexibility was necessary in order to render the study of mass phenomena "a catalogue not of social aberrations but of processes which, in different degrees, structure any kind of socio-political life" (40, original emphasis). This turn will come with Freudian psychopathology as an interpretive key for human behaviour in general. Sighele is not Freud, but he addresses the need for a nuanced approach to forms of human aggregation, and provides numerous poignant examples that break down the dualism between social homogeneity and social differentiation. ${ }^{45}$

While theories of crowd behaviour evolved considerably since The Criminal Crowd, masses have continued to captivate, alarm, or repel twentiethcentury's intellectuals, from Émile Durkheim's collective effervescence and Ortega y Gasset's revolt of the masses, down to Elias Canetti's analysis of crowd dynamics in relation to the power of rulers, Hannah Arendt's treatment of masses as the quintessential totalitarian phenomena, and Michel Maffesoli's studies of the irrational, tribal behaviour of contemporary Western collectivities, among many others.

Significantly, both the crowd's unpremeditated boundless destructiveness and more sophisticated and intentional forms of collective behaviour investigated by Sighele continue to intrigue contemporary historians and sociologists, who, however, problematize abstract univocal definitions. Neither a savage rabble nor a fully purposeful collectivity emerges, for instance, from the historian George Rudé's 1956 analysis of the Gordon Riots, the most devastating outburst of urban violence in British history, against the repeal of the 1778 Papists Act aiming to reduce anti-Catholic discrimination. Determined to offer a portrait of pre-industrial rioters, identifying their patterns and motives rather than treating them in bulk as mob (Rudé "Gordon" 94), Rudé seems to substantiate Sighele's views when he dismisses the hypothesis of premeditation and rather supports the idea of an impulsive multitude managed by local leaders "by temporary circumstance" (103). But, ultimately, he explains the crowd's drive "to destructive violence" (106) as the conscious expression of a desire for social justice propelled by a variety of political and economic, rather than merely religious, grievances. Rejecting the interpretation of a "fickle, irrational, violent" (Crowd 252) mob, Rudé tempers the generalizations of late nineteenth-century collective psychology by highlighting

45 It is surprising, therefore, that Laclau himself mentions Sighele only once, and extremely superficially, in his discussion of the Lombrosian school, while he pays attention to nuances in Tarde's treatment of public opinions that in his view anticipate Freud's theories. 
the different social and historical contexts and the multiple coexisting motivations behind public disorders.

Along similar lines, although E.P. Thompson acknowledges the role of particular individuals acting as initiators of sudden upheaval, like Sighele's suggestionizers, ${ }^{46}$ his concept of "the moral economy" (Customs 185) of the eighteenth-century English crowd in his seminal 1971 study refutes the "spasmodic view of popular history" (185) by invalidating the reductive image of riots prior to the French Revolution as "compulsive, rather than self-conscious or self-activating" (185) interventions, and by ascribing, instead, a "complex, culturally mediated function" (187) to mass insurrections. Well beyond elementary, instinctive, violent reactions to the basic stimulus of hunger and distress, for instance, Thompson offers an interpretation of eighteenth-century English food riots as sophisticated patterns of collective behaviour propelled by "custom, culture, and reason" (187), expressing grievances against the breakdown of shared "social norms" (188) and "moral imperatives" (269) that regulated and negotiated economic roles among the different parties within the community.

Nonetheless, the empirical and theoretical implications of Scipio Sighele's analysis of mass society and the power of crowds as both agents of destruction and promoters of change have not lost their relevance, if we consider, for instance, the dynamics and effects of the soccer fan riots that periodically erupt in Europe, the violent popular uprisings that overthrew Romanian dictator Ceausescu in 1989, the "people power" movements that toppled Philippine presidents Marcos in 1986 and Estrada in 2001, ${ }^{47}$ or the more recent massive demonstrations that

46 For the coinage of this term as the English rendition of Sighele's "suggestionatore," see "A Note on the Texts and Their Translations" in this volume.

47 Both the crowd's influence upon political events and its manipulation (what in Sighele would be suggestion) for specific agendas emerge from a recent study of the "People Power II" movement, focusing on the attempt by the middle class to co-opt the masses to support their demands to the state by using communication technologies. See Vincent Rafael, "The Cell Phone and the Crowd" (2003). I am grateful to the anonymous reader who directed me to this article.

Likewise, contemporary news shows us that Sighele's attention to the dynamics of crimes à deux is more than ever timely. One emblematic Italian "criminal couple" that corroborates Sighele's succubus-incubus relationship can be found in the 2001"Novi Ligure murder," in which 16-year-old Erika De Nardo slaughtered her mother and brother with the complicity of her suggestionable 17-year-old boyfriend Omar Favaro, whom she had brainwashed. Similarly, in the January 2017 double murder at Pontelangorino, husband Salvatore Vincelli and wife Nunzia Di Gianni were killed by their 16-year-old son and his allegedly weaker-minded 17-year-old friend. 
contributed to the downfall of Egyptian President Mubarak in 2011. Recent scholarship in the humanities and social sciences confirms the relevance of Sighele's contribution beyond a mere historical interest for its own sake. In his book The Crowd and the Mob, an examination of the idea of the crowd in history from Plato to Canetti, J.S. McClelland foregrounds the pivotal role that Sighele played in the shift from a mere criminological approach to crowds to a more general sociological theory treating collectivities as permanent and modern, rather than occasional, social factors (162-65). Even more radically, Christian Borch in The Politics of Crowds inserts Sighele in a trajectory of scholars who demonstrate that crowds are not just exceptional phenomena, In fact, crowds have been and continue to be central to the understanding of society.

Scipio Sighele did not just write for his own time. He can and should still be read-with his insights, inconsistencies, and even inadmissible claims-as a reference figure in the Italian and European history of an idea that has not ceased to speak to us. The radical oppositional power of sectarian violence, the effects of suggestion exerted by group ideologies upon easily influenced minds, the power of collectivities as agents of innovation, and the danger of mass fanaticism undermining individual freedom and democratic ideals are issues more relevant than ever in our globalized but deeply fragmentary present.

\section{Bibliography}

Altrocchi, Rudolph. “An Eminent Sociologist.” The Nation. 97, 2524

(13 Nov. 1913): 457-58.

Ambrosoli, Francesco. Salviamo il Parlamento! In risposta all'opuscolo di S. Sighele Contro il Parlamentarismo. Milan: Treves, 1895.

Anderson, Benedict. Imagined Communities. London: Verso, 1991 [1983].

Bissolati, Leonida. "Pseudopositivismo." Critica sociale (1 May 1895).

Bodei, Remo. Destini personali. Milan: Feltrinelli, 2002.

Borch, Christian. The Politics of Crowds: An Alternative History of Sociology.

Cambridge: Cambridge University Press, 2012.

Bosc, Olivier. La foule criminelle: Politique et criminalité dans l'Europe du tournant du XIXe siècle. Paris: Fayard, 2007.

- "De la foule criminelle à la foule nationaliste: Scipio Sighele, théoricien de l'irrédentisme." Matériaux pour l'histoire de notre temps 43 (1996): 44-45. 
Castellini, Gualtiero. "Introduzione biografica." In Scipio Sighele, Letteratura e sociologia. Milan: Treves, 1914, i-xxi.

Chamberlain, A.F. "Report by the Italian Commission on Physical Education." Journal of Genetic Psychology 3 (1893): 164.

Chimienti, Pietro. La vita politica e la pratica del regime parlamentare. Turin: Roux Frassati e Co. Editori, 1897.

Engels, Friedrich. "Against Vulgar Marxism.” In Marxist Literary Theory. Edited by Terry Eagleton and Drew Milne. Oxford: Blackwell, 1996, 39.

- "On Realism." In Marxist Literary Theory. Edited by Terry Eagleton and Drew Milne. Oxford: Blackwell, 1996, 40-41.

Ferrari, Robert. "Sighele on Adulteration of the Positive Doctrines in Collective Crimes." Journal of the American Institute of Criminal Law and Criminology 3, 4 (Nov. 1912): 616-17.

Ferri, Enrico. I delinquenti nell'arte. Genoa: Libreria Editrice Ligure, 1896.

- "Nota di Enrico Ferri." In Scipio Sighele, La folla delinquente II ed. Turin: Bocca, 1895, 157-66.

Freud, Sigmund. Group Psychology and the Analysis of the Ego. The Standard Edition of the Complete Psychological Works of Sigmund Freud, vol. XVIII (1920-22). Translated by James Strachey. London: Hogarth Press, 1949.

- Interpretation of Dreams (1900). The Standard Edition of the Complete Psychological Works of Sigmund Freud. Translated by James Strachey. London: Hogarth Press, 1955.

Gallini, Chiara. "Introduzione.” In Scipio Sighele, La folla delinquente. Edited by Chiara Gallini. Milan: Marsilio, 1985, 7-42.

Garbari, Maria. "Il pensiero politico di Scipio Sighele." Rassegna storica del Risorgimento LXI (1974): 391-426, 523-61.

Giachetti, Cipriano. "Scipio Sighele." La Nuova Antologia 49, 1009 (1 Jan. 1914): 94-102.

Ginneken, Jaap van. Crowds, Psychology, and Politics, 1871-1899. Cambridge: Cambridge University Press, 1992.

Gorni, Mariagrazia, and Laura Pellegrini. Un problema di storia sociale: L'infanzia abbandonata in Italia nel secolo XIX. Florence: La Nuova Italia, 1974.

Irigaray, Luce. "Women on the Market." In This Sex Which Is Not One. Translated by Catherine Porter. Ithaca: Cornell University Press, 1985.

Isastia, Annamaria. "La battaglia per il voto nell'Italia liberale.” In Dal diritto di voto alla cittadinanza piena. Edited by Marisa Ferrari Occhionero. Rome: Università la Sapienza, 2008, 31-51.

Jacobsen, Rosalia. "Inchiesta sulla donna e il problema dell'amore, “ Pagine libere. Rivista quindicinale di politica, scienza e arte, 21 (1 Nov. 1908): 1-12.

Labriola, Teresa. "Cronaca del femminismo." Rivista di Roma 11 (Jan. 1907): 48-51. 
Laclau, Ernesto. On Populist Reason. London:, Verso, 2005.

Le Bon, Gustave. Psychologie des foules. Paris: Alcan, 1895.

Lombroso, Cesare. "Il delinquente e il pazzo nel dramma e nel romanzo." Nuova antologia XXXIV (1889): 665-81.

Lukács, Georg. The Historical Novel. Translated by Hannah and Stanley Mitchell. Lincoln: University of Nebraska Press, 1983.

- "The Ideology of Modernism." In The Critical Tradition: Classic Texts and Contemporary Trends, David H. Richter, ed. 3rd ed. Boston: Bedford/ St Martin's Press, 1218-32.

Mantegazza, Paolo. The Physiology of Love. In The Physiology of Love and Other Writings. Edited and introduced by Nicoletta Pireddu. Translated by David Jacobson. Toronto: University of Toronto Press, 2007.

Marinetti, Filippo Tommaso. "The Founding and Manifesto of Futurism." In Futurism: An Anthology, Lawrence Rainey, Christine Poggi, and Laura Wittman, eds. New Haven: Yale University Press, 2009, 49-53.

Mazzini, Giuseppe. The Duties of Man. London: Chapman and Hall, 1862.

-."Europe: Its Conditions and Its Prospects." In Five Views on European Peace, Sandi E. Cooper, ed. New York: Garland, 1972.

- "Pensieri: Ai poeti del XIX secolo." In D’una letteratura europea e altri saggi, Paolo Maria Sipala, ed. Fasano: Schena, 1991, 93-118.

McClelland, J.S. The Crowd and the Mob. London: Unwin Hyman, 1989. McPhail, Clark. The Myth of the Madding Crowd. New York: DeGruyter, 1991. Melzi, Costantino. Antropologia pedagogica. Arona: Tipografia Economica, 1899. Merlini, Stefano. "Il governo costituzionale." In Storia dello Stato italiano dall'unità a oggi, Raffaele Romanelli, ed. Rome: Donzelli, 1995, 1-72. Miceli, V. "Come salvare il Parlamento." Riforma Sociale (10 Sept. 1895). Micklem, Nathaniel, and Herbert Morgan. Christ and Caesar. New York: Macmillan; London: Swarthmore Press, 1921.

Moscovici, Serge. The Age of the Crowd. Cambridge: Cambridge University Press, 1985.

Palano, Damiano. Il potere della moltitudine. Milan: Vita e Pensiero, 2002.

Park, Robert E., and Ernest W. Burgess, eds. Introduction to the Science of Sociology. Chicago: University of Chicago Press, 1921.

Pellegrino, Ettore Lombardo. La questione del Parlamentarismo. Florence: Casa Editrice Libraria "Fratelli Cammelli," 1896.

Pirandello, Luigi. "Feminismo.” In Saggi, poesie, scritti varii. Edited by Manlio LoVecchio Musti. Milan: Mondadori, 1977, 1068-72.

Pireddu, Nicoletta. "Paolo Mantegazza: A Scientist and His Ecstasies." In Paolo Mantegazza, The Physiology of Love and Other Writings. Edited and introduced by Nicoletta Pireddu. Translated by David Jacobson. Toronto: University of Toronto Press, 2007, 3-53. 
Poe, Edgar Allan. "The Man of the Crowd." In Selected Tales. Oxford: Oxford University Press, 1980, 97-104.

Rafael, Vincent. "The Cell Phone and the Crowd: Messianic Politics in the Contemporary Philippines." Public Culture 15, 3 (2003): 399-425.

Romani, Gabriella. "Interpreting the Risorgimento: Blasetti's 1860 and the Legacy of Motherly Love." Italica 79, 3 (2002): 391-404.

Rudé, George. The Crowd in History: A Study of Popular Disturbances in France and England. New York: Wiley, 1964.

- "The Gordon Riots: A Study of the Rioters and Their Victims: The Alexander Prize Essay." Transactions of the Royal Historical Society 6 (1956): 93-114.

Schinz, Albert. "Psychological Literature." American Journal of Psychology IX $(1897-8): 416$.

Schnapp, Jeffrey, and Matthew Tiews, eds. Crowds. Stanford: Stanford University Press, 2006.

Sergi, Giuseppe. "Il movimento femminista." Rivista politica e letteraria (April 1898): 3-12.

- "Psicosi epidemica." Rivista speciale di opere di filosofia scientifica 8 (1889): 151-72.

Sighele, Scipio. Eva moderna. Milan: Treves, 1910.

- Il nazionalismo e i partiti politici. Milan: Treves, 1911.

- "Individual Morality and Political Morality - A Sociological Problem." To-morrow: A Monthly Review (Aug. 1896; Oct. 1896): 218-25.

- La coppia criminale: Saggio di psicologia morbosa. Turin: Bocca, 1892.

- La delinquenza settaria. Milan: Treves, 1897.

- La donna nova. Rome: Enrico Voghera Editore, 1898.

- La folla delinquente: Saggio di psicologia collettiva. Turin: Bocca, 1891; II ed. Turin: Bocca, 1895.

- "La nouvelle psychologie irrédentiste depuis l'expédition tripolitaine." La Revue 6 (15 March 1912): 145-56.

- "Latin Europe and American Imperialism." The International Monthly: A Magazine of Contemporary Thought (Jan. 1902): 655-70.

- Letteratura e sociologia. Milan: Treves, 1914.

- Letteratura tragica. Milan: Treves, 1906.

- L'intelligenza della folla. II ed. Turin: Bocca, 1911.

- Nell'arte e nella scienza. Milan: Treves, 1911.

- Pagine nazionaliste. Milan: Treves, 1910.

- Mentre il secolo muore. Milan-Palermo: Remo Sandron Editore, 1899.

- "The Moral Problem of Collective Psychology." The Humanitarian (April 1901): 242-52.

- "Una pirateria letteraria: Le Bon, La Psychologie des foules." La scuola positiva V, 3 (1895): 171-73. 
- Unpublished letter to Giovanni Pedrotti, 30 Aug. 1908. Fondo Sighele, Biblioteca della Fondazione Museo Storico del Trentino, Trento, Italy.

Stewart-Steinberg, Susan. The Pinocchio Effect. Chicago: University of Chicago Press, 2007.

Tarde, Gabriel. L'opinion et la foule. Paris: PUF, 1989 [1901].

Thompson, Edward Palmer. Customs in Common. New York: New Press, 1991.

Virgilii, Filippo. "Lo sciopero nella vita moderna." Studi senesi 14 (1897): 4-40.

Wells, H.G. Men Like Gods. New York: Macmillan, 1923.

Wilde, Oscar. "The Soul of Man under Socialism." In The Complete Works of Oscar Wilde, vol. 4. Edited by Josephine M. Guy. Oxford: Oxford University Press, 2007.

Zimmern, Helen. “An Indictment of Parliaments.” Blackwood's Edinburgh Magazine 58 (Aug. 1895): 227-33.

- "Criminal Anthropology in Italy." Popular Science Monthly 52 (April 1898): 743-60. 